\begin{tabular}{|l|l|}
\hline Contribución a la historia de las instituciones coloniales en Guatemala & Titulo \\
\hline Zavala, Silvio - Autor/a; & Autor(es) \\
\hline & Lugar \\
\hline El Colegio de México & Editorial/Editor \\
\hline 1945 & Fecha \\
\hline Jornadas no. 36 & Colección \\
\hline Indígenas; Colonia; Historia; Esclavos; Guatemala; & Temas \\
\hline Libro & Tipo de documento \\
\hline "http://biblioteca.clacso.org/Mexico/ces-colmex/20200916031658/jornadas-36.pdt" & URL \\
\hline $\begin{array}{l}\text { Reconocimiento-No Comercial-Sin Derivadas CC BY-NC-ND } \\
\text { http://creativecommons.org/licenses/by-nc-nd/2.0/deed.es }\end{array}$ & Licencia \\
\hline
\end{tabular}

Segui buscando en la Red de Bibliotecas Virtuales de CLACSO http://biblioteca.clacso.org

Consejo Latinoamericano de Ciencias Sociales (CLACSO)

Conselho Latino-americano de Ciências Sociais (CLACSO)

Latin American Council of Social Sciences (CLACSO)

www.clacso.org

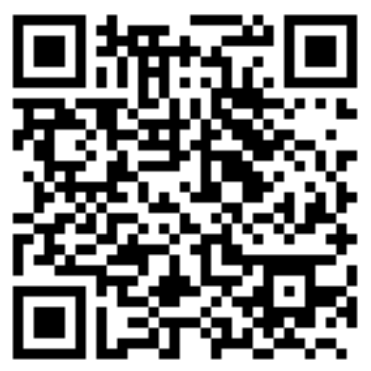




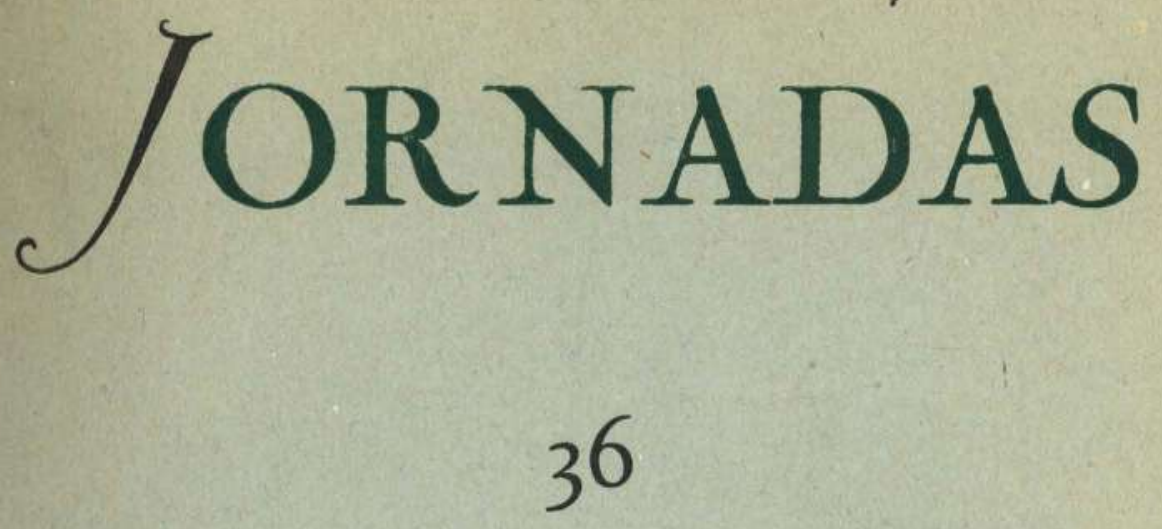

SILVIO ZAVALA

Contribución a la historia de las instituciones . coloniales en Guatemala. 


\section{EL COLEGIO DE MEXICO SEVILLA, 30 MEXICO, D. F.}

\section{JUNTA DE GOBIERNO}

Alfonso Reyes, Presidente; Eduardo Villaseñor; Gustavo Baz; Gonzalu Robles; Enrique Arreguín Jr.; Daniel Cosío Villegas, Secretario.

CENTRO DE ESTUDIOS SOCIALES

Director: Dr. José Medina Echavarría

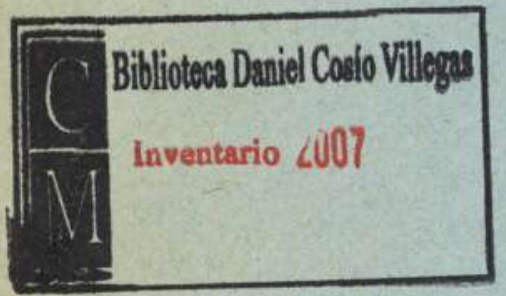

CENTRO DE ESTUDIOS HISTORICOS

Director: Dr. Silvio Zavala

CENTRO DE ESTUDIOS LITERARIOS

Director: Dr. Alfonso Reyes

SEMINARIO SOBRE EL PENSAMIENTO HISPANO-AMERICANO

Director: Dr. José Gaos

\section{J O R N A D A S}

Organo del Centro de Estudios Sociales

Director: J. Medina Echavarria; Secretario: F. Giner de los Ríos.

(Toda la correspondencia literaria debe enviarse a Sevilla 30, México, D. F.).

Distribución exclusiva: Fondo de Cultura Económica

Pánuco 63 


\section{$13767310 \mathrm{~km}$

Jornadas, órgano del Centro de Estudios Sociales de El Colegio de México, nació al calor de un seminario colectivo sobre la guerra que celebró dicho Centro en 1943. La publicación se prosiguió durante los meses siguientes para reflejar la labor realizada en otro seminario sobre los problemas de América Latina. Cubiertas estas dos etapas, JoRNADAs va a convertirse ahora en lo que había de ser desde un principio: en órgano expresivo permanente del Centro de Estudios Sociales del Colegio y no ya sólo de actividades circunstanciales suyas.

Ante el nuevo carácter de JoRNadas, conviene fijar en breves palabras el sentido que quiere imprimirse a la publicación, las razones que empujan a emprenderla.

Es un tópico que ha llegado ya de los círculos científicos a los medios populares, que nuestro siglo es o debe ser el siglo de la ciencia social, por razón del desequilibrio hoy existente entre nuestro saber cientifico sobre la naturaleza y nuestro saber científico sobre el hombre y su actividad. Los resultados de la labor de las pasadas centurias, especialmente de la última, en el dominio de la ciencia natural, son hoy tangibles para todos y le han otorgado a nuestra vida un poder sobre los fenómenos naturales come nunca antes se soñara. En cambio, el pensamiento racional y científico apenas comienza a conquistar lo que nos es más próximo: nuestra propia vida y su organiza. ción. Los acontecimientos actuales prueban de qué manera el dominio de la naturaleza, la ciencia y la técnica, se frustran y son adversos al hombre cuando éste no maneja todavía otros instrumentos que guíen su propio destino. Nada más necesario hoy que el tratamiento científico, es decir, racional y objetivo, de las cuestiones humanas, pues el futuro de nuestra civilización, de toda posible civilización, en las presentes circunstancias, depende de que se puedan dominar, o no, la naturaleza 
humana la vida social en un grado semejante a como nos es dado regular la naturaleza fisica. JoRNADAs se propone ante todo mantener despierta la conciencia de este problema y coadyuvar con todas sus energias a los esfuerzos ya emprendidos para llegar a su solución.

Ahora bien, las cuestiones humanas no pueden ser tratadas en el vacio; surgen problemas, dificultades $y^{*}$ conflictos ofrecidos en circunstancias y momentos determinados, y la investigación científica de los mismos sólo tiene sentido si sus resultados resuelven la situación problemática, despejan la dificultad o atenúan el conflicto, liberando al hombre de su angustiosa presión. Esto quiere decir que no son las teorías las que determinan los problemas, sino éstos los que deben dar lugar al pensamiento teórico $y$, además, que no puede entenderse ni solucionarse ningún problema de la vida humana si lo desprendemos de su contexto o circunstancialidad. El olvido de este punto de partida elemental es quizá el responsable de la situación de atraso de las ciencias del hombre, como también de que las disciplinas sociales arrastren una pesada herencia de teorías que ya no responden a ninguna cuestión auténtica.

Asimilando el sentido de esa perspectiva, en las Jornadas no se desdeñará, en modo alguno, el pensamiento social teórico actual, cualquiera que sea el punto del horizonte de donde proceda, y a su discu. sión y examen habrá que concederle atención cuidadosa; pero, en lo posible, sometiéndolo a la prueba de su validez para nuestros medios. En una palabra, lo que interesa de un modo fundamental son: a) las cuestiones humanas en su específica circunstancialidad americana, y b) los problemas "nuestros" que exigen una meditación teórica y una solución práctica.

En consecuencia, no se rechaza la consideración de las teorías y resultados de la ciencia social en general; pero se cree que la verdadera tarea intransferible está en estudiar y hacer que se estudien las cuestiones especificas de la facción latina del continente americano, de modo que soluciones y teorias no provengan de una importación 
más o menos afortunada, sino que broten de la investigación misma de nuestras situaciones problemáticas peculiares.

La tragedia de Europa al privarnos de su producción intelectual y científica, siempre recibida con la sugestión de su viejo prestigio, nos obliga a un doble esfuerzo, que conviene que sea lo más consciente posible: por una parte, a que pensemos por nosotros mismos y sin andaderas $y$, por otra, a que meditemos hasta qué punto todo lo que nos viene del otro lado del Atlántico merece ser aceptado y asimilado y si no ha perdido aguel continente en más de algún punto el derecho al respeto que se le otorgaba sin discusión. Y pensando muy en particular en "nuestra América", estamos convencidos de que ésta ha de ponerse enérgicamente a pensar en sí misma en su propio destino y a aprovechar lo que es un triste momento para conquistar definitivamente, sin renunciar a ninguna herencia valiosa, su autonomía cultural.

En cuestiones sociales y políticas es esto tanto más urgente cuanto mayor es la sospecha de que lo que se nos ofrece por varios lados no es dádiva generosa sino velado instrumento de dominación. $Y$ sólo podremos mantenernos relativamente inmunes de las consecuencias sociales y culturales de las tremendas luchas de poder hoy en juego, si conservamos la serenidad intelectual y el conocimiento preciso y objetivo de los hechos. Una visión acertada de nuestro presente y nuestro futuro es lo único que puede permitirnos sacar ventajas, incluso de lo que parecen adversas constelaciones.

Dentro de la dirección general antes esbozada, las JoRnadas del Centro de Estudios Saciales de El Colegio de México quieren presentar un amplio marco a la colaboración: desde las cuestiones filosóficas conexas, hasta los estudios de la ciencia social más particular y especializada; pero viendo también dibujados dentro de ese marco estos tres propósitos fundamentales: 1) exponer el estado actual de la ciencia, de conocimiento imprescindible, como punto de partida;2) examinar y discutir, en particular, los problemas peculiares de la ciencia en nuestros países, y 3) contribuir en lo posible al desarrollo de la ciencia social en marcha. 
Desde el punto de vista científico, con JoRnaDas se intentará fomentar el estudio de las cuestiones marginales y fronterizas de las ciencias tradicionales y académicas, que es donde se encuentran hoy día los problemas auténticos de la ciencia social futura. $Y$ desde el punto de vista político, en su mejor sentido, conseguir el conocimiento recíproco de los pueblos de nuestra América, manteniendo asi viva y real la conciencia de su común destino. 

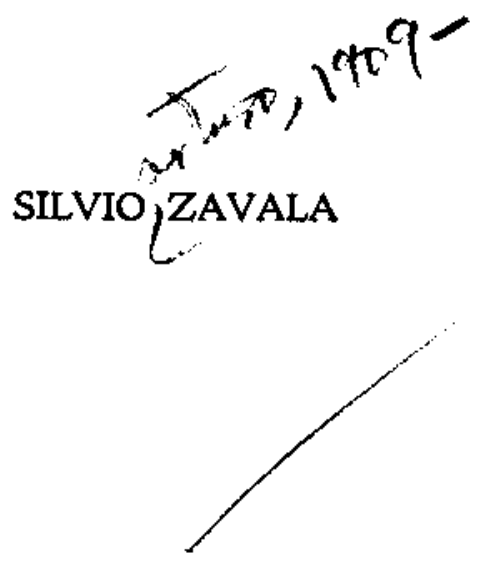

\title{
Contribución a la historia de las instituciones coloniales en Guatemala
}

Open access edition funded by the National Endowment for the Humanities/Andrew W. Mellon Foundation Humanities Open Book Program.

\section{(c)}

The text of this book is licensed under a Creative Commons Attribution-NonCommercialNoDerivatives 4.0 International License: https://creativecommons.org/licences/by-nc-nd/4.0/

\author{
JORNADAS - 36 \\ El Colegio de México \\ Centro de Estudios Sociales \\ 1945
}




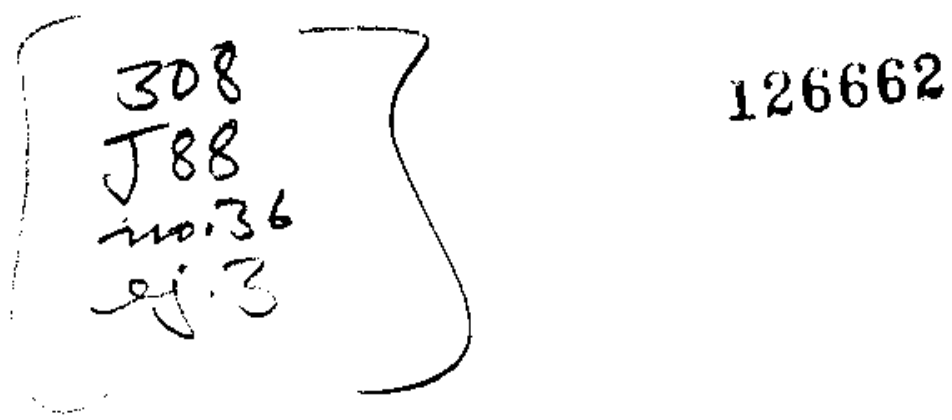

Imprega en los 1alleted de la Enitoriat, Styro, Durango 290. Miexico, D. F. 
$k$

$\frac{1}{8}$

SUMARIO

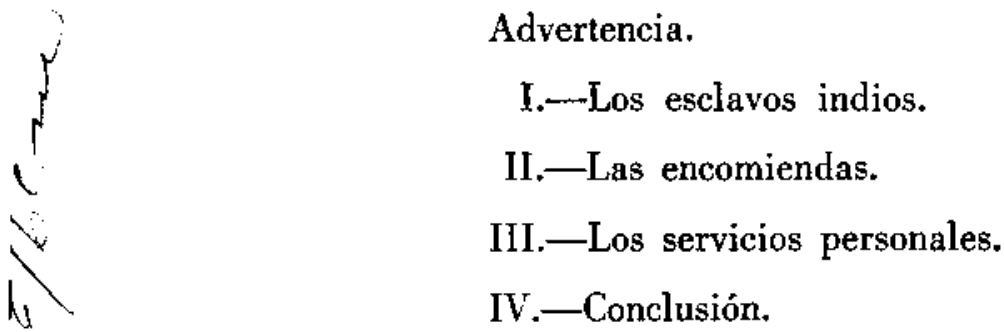





\section{A D V E R T E N C I A *}

Es bien sabido que la conquista de América fué obra de capitanes y soldados que contribuían con sus personas y haciendas a ganar los reinos que se incorporaban en la Corona de Castilla.

Ena de esperar que los conquistadores y pobladores, después de las batallas, hicieran probanzas de sus méritos y servicios para obtener los premios a que se consideraban acreedores.

La base económica de esos premios consistia en diversas cosas $y$ servicios que daban los indios conquistados. Tales contribuciones llegaban a manos de los españoles a través de instituciones sociales bien demarcadas, como la esclavitud, las encomiendas y los servicios personales.

El proceso de organización de estas instituciones $y$ el de su funcionamiento una vez constituídas no puede ser comprendido sin tomar en cuenta la sucesión de épooas, la variedad de los intereses egoístas y justicieros que entraban en juego y las modalidades propias de cada provincia.

En este estudio me propongo analizar algunos aspectos de ha historia institucional de Guatemala. He podido consultar varios manuscritos existentes en la oapital del propio país, asi como otras fuentes complementarias, pero no pretendo en manera alguna haber agotado las posibilidades de investigación que ofrece este campo.

* Para preparar este trabajo conté con la ayuda de la Fundación Rockefeller y de EF Colegio de México. El director del Archivo General del Gobierno de Guatemała, don J. Josquín Pardo, me dió toda clase de facilidades para realizar mi labor. Don Antonio Goubaud me proporcionó un interesante manuscrito de su propiedad que examino en el lugar apropiado del texto. Expreso mi agradecimiento a las instituciones y personas nombradas. 



\section{LOS ESCLAVOS INDIOS}

De acuerdo con las prácticas de guerra de los conquistadores de Nueva España, cuando Pedro de Alvarado realizó en 1524 la conquista de Guatemala, se hicieron esclavos indios en Cuzcatan, Izcuyntepeque, Pazaco, Acaxocal y Tuculcalco. ${ }^{1}$

Razonaba Alvarado que aunque en su expedición se matasen e hiciesen esclavos algunos indios, no por eso se despoblaba la tierra; los soldados iban a su costa, y dada la multitud de indios y el corto número de los cristianos, no se conquistaría si no fuese por los castigos. ${ }^{2}$

Además de los esclavos de guerra, los españoles contaron con los in-

1 Cfr. Sumario de la residencia tomada a Don Hernando Cortés, México 1852-1853, I, 96, 155, 197 y 233. Y Procesos de residencia instruidos contra Pedro de Alvarado y Nuño de Guzmán, México, 1847, pp. 7, 57,62 y 77. I a manera como se planteaba entonces la conquista llevaba consigo la probabilidad de que hubiers esclavos de guerra. Por ejemplo, escribía Alvarado a Cortés, el 11 de abril de 1524, que envió mensajeros a la tierra de Soconusco para hacer saber cómo venía a conquistar y pacificar las provincias que so el dominio de su majestad no se quísiesen meter, y a ellos como a vasallos, pues por tales se habían ofrecido, les pedía favor y ayuda y entrada por su tierra: "que haciéndolo asi, que harian como buenos y leales vasallos de su majestad, y que de mí y de los españoles de mi compañía serian muy favorecidos y mantenidos con toda justicia; y donde no, que nnrotestaba de hacerles la guerra como a traidores rebelados y alzados contra el servicio del Em* perador nuestro señor, y que por tales los daba; y demás de esto, daba por esclavos a todos los que a vida se tomasen en la guerra". Libro viejo de la Fundación de Guatemala, Guatemala, 1934, n. 271. Cit. por J. A. Villacorta C., Prehistoria e Historia Antigua de Guatemala, Guatemala, 1938, pp. 328-329. En esta última obra, p. 339, se dice que una vez muertos los señores de Utatlan, los prisioneros de gaerra fueron vendidos entre los españoles, y el quinto de su producto entregado al tesorero real. Durante algunos años continuaron estas prác. ticas de guerra. En 1529, Jorge de Alvarado que ejercía la gobernación de Guatemale por don Pedro, atacó a los indios capitaneados por el cacique Tonaltetl, y de esa época data la formación del pueblo de Los Esclavos a orillas del río llamado así desde entonces, y que habitaron los indios vencidos en aquella campaña. Ibid., p. 389. En 1530, el cabildo de Gua. temala envía tropas a la provincia del Salvador al mando de Francisco López; cuando llegaron ya había partido Martin de Estete, quien pretendía que la provincia era de Nicaragua, y llevó consigo 2,000 indios cuscatlecos en calidad de esclavos, los que fueron recobrados por las tropas de López. Ibid., p. 394.

2 Procesos de residencia, cit., pp. 62 y ss. 
dios que de conformidad con las costumbres de la sociedad prehispánica desempeñaban tareas serviles y que, por compras, tributos o tratos de otra indole, pasaban de manos de los amos indígenas a las de los europeos. Fueron los llamados esclavos de rescate. ${ }^{3}$

La razón de la esclavitud de los indios había comenzado a ser discutida en las esferas religiosas y de gobierno de España e Indias. Pesaba la experiencia desgraciada de la despoblación de las islas Antillas y de la costa de Tierra Firme. En Nueva España se cometieron abusos cuando Cortés marchó a las Hibueras y bajo el gobierno de la Primera Audiencia presidida por Nuño de Guzmán. Este hizo esclavos, además, en las provincias de Pánuco y Nueva Galicia que gobernó. Pero en 1530, el nombramiento de la Segunda Audiencia de México, presidida por el obispo D. Sebastián Ramírez de Fuenleal, hizo posible una interven. ción más rigurosa del poder real en las relaciones de los españoles con los nativos.

En lo que concierne particularmente a la esclavitud, la Reina dió una cédula en Madrid, a 2 de agosto de 1530, en que explicaba a las Audiencias de la ciudad de Santo Domingo de la Isla Española y de la

3 En la sesión que celebró el Ayuntamiento de Guatemala el 23 de agosto de 1529, se señalaron los emolumentos "que oviere de llevar o llevare la persona que herra los esclavos del resgate; haya o lleve de salario e premio dellos de veinte uno, e que no haya escribano al herradero por evitar costas e gasto de los vecinos desta dicha cibdad". Libro Viejo de la Fundación de Guatemala, cit., p. 85. Y Villacorta, Prehistoria..., cit., p. 39l. En relación con este tema cuenta Remesal que Pedro de Alvarado había dado poder al obispo Marroquín de Guatemala para que hiciera por él su testamento. Este lo otorgó el 30 de junio de 1542 , dando por libres a Ios esclavos que tenía el Adelantado en la labranza de Jocotenango y a los que le sacaban oro en las minas; unos y otros los habia obtenido pidiéndolos a los indios que tenía en encomienda y los había hecho herrar sin preceder otro examen. El Obispo referia en la cláusula del testamento que muchas veces djjo a Alvarado que esos indios habian sido esclavizados jndebidamente "y así él lo conoció y por tener tantas deudas como dejó no osaba hacer lo que convería a su conciencia. E siempre el dicho Adelantado me decía que cuando se viese sin deudas dejaría libres a los dichos esclavos". En consecuencia, Marroquín puso en libertad a los esclavos de la labranza, permitiéndoles quedarse con las tierras en que estaban. Asimismo emancipó a los esclavos, hombres, mujeres e hi. jos, que sacaban oro, con la condición de que sacaran el que se necesitara para pagar las deudas del Adelantado, pot no haber otros bienes ni rentas de donde se pudieran pagar. Mientras trabajaran en esto, serían bien mantenidos, curados, tratados y doctrinados a costa del oro que sacaran. Una vez pagadas las deudas, sacarian oro durante una demora, de primero de octubre hasta San Juan, para repartir a los hijos naturales del Adelantado. Después estos indios sc pondrían en la milpa en tierras que no se labraban y se les darían éstas para que hicieran sus siembras de trigo y maíz. De las sementerás de todos los esclavos emancipados, asi de la labranza como de las minas, se pagarían los salarios de cuatro capellanes en. cargados de enseñar la doctrina. Historia gencral de las Indias Occidentales y particular de la gobernación de Chiapa y Guatemala, Guatemala, 1932, I, 262-263. 
ciudad de México de la Nueva España, así como a todos los gobernadores, corregidores, alcaldes mayores y otros jueces de Indias, que al principio de los descubrimientos, los Reyes Católicos permitieron cautivar y hacer guerra a ciertos indios que resistían con mano armada a los predicadores de la fe católica; que eso fué tolerado después por don Carlos y doña Juana "como cosa que por derecho e leyes de nuestros reinos se podría sin cargo de nuestra conciencia hacer e permitir"; pero considerando los muchos e intolerables daños que se habían seguido por la desenfrenada codicia de los conquistadores, se mandaba ahora que nadie en tiempo de guerra, aunque fuese justa, osara cautivar a los indios, y que tampoco pudieran ser obtenidos por vía de rescate. Los dueños de indios esclavos, dentro de treinta días del pregón de esta cédula, quedaban obligados a manifestarlos ante la justicia, donde se formaría una matrícula, "para que sepan los que verdaderamente son esclavos, e de ahí adelante no se puedan hacer más". 4

Ignoro cuándo llegó esta cédula a Guatemala; a ella parece referirse la carta de la Audiencia de México a la Emperatriz, de 30 de marzo de 1531, en que avisa:

"En Guatimala se platicaba (sic., ¿por practicaba?) mucho el herrar de los esclavos y se cargaban por aquella vía que navegan para $\mathrm{Pa}$ namá; enviamos allá provisión que cerca dello vuestra majestad nos mandó dar e dirigimos al dicho fray Domingo de Betanzos y en su absencia a otra buena persona que nos enviase el testimonio de la publicación della; tendremos especial cuidado de saber cómo se guarda". 5

El disgusto que ocasionó a los españoles esa cédula antiesclavista se refleja en la representación que elevó el Ayuntamiento de Guatemala al Rey. Explica que se ha comenzado a sacar oro con algunos esclavos que hay en la tierra, y ahora su majestad manda que no se ha. gan ni hierren esclavos de guerra ni rescate, siendo la general mercaduría que entre ellos (parece referirse a los indios) anda y con que contratan; lo cual el Rey debe mandar porque debió ser informado que

\footnotetext{
4 Vasco de Puga, Provisiones..., México, 1879. I, 231.

5 Epistolario de Nueva España, ed. por Francisco del Paso y Troncoso, México, 1939 , II, 59.
} 
los indios de estas partes son como los de la Nueva España, donde por haber tanto tiempo que están conquistados y ser gente de razón y aplicada a todo bien se podía mejor sufrir que no en esta gobernación, por carecer de todo lo susodicho y aún no estar acabada de conquistar. Se sufre más que no se dejen de hacer dichos esclavos en esta tierra que en otra ninguna, porque la gente es indomable y contumaz, y para tenerlos seguros y sujetos al servicio de su majestad hay necesidad de que piensen que no les han de dejar salir con sus sacrificios ni otros muchos excesos que cada día cometen; y los esclavos que ellos entre sí tienen, de darlos a los españoles, resulta, demás de ayudarles en alguna cosa, que no los sacrifican a sus ídolos y los comen, como es entre ellos costumbre de hacer; además de esto, algunos o la mayor parte de tales esclavos, andando entre los españoles, se convierten a la fe católica y serán buenos cristianos; y sobre todo, el Rey perderá mucha suma de pesos de oro a causa de que ahora comienzan a gozar los españoles del fruto que los indios les dan en darles algunos esclavos para su servicio y sacar oro, lo cual habrá de cesar por lo que su majestad tiene mandado. Suplican, en consecuencia, que por siempre o por el tiempo que el Rey fuere servido se hagan y hierren los dichos esclavos, así de guerra como de rescate, pues en el hacer de ellos se ha guardado y guardará la orden que el Rey manda que se guarde en la Nueva España, y que dicho mando (es decir, el que prohibe que se hagan esclavos de guerra y de rescate) no se entienda en la gobernación, porque pueda gozar como gozó la Nueva España de esta libertad hasta que esté en términos que sin ella se pueda pasar. En otro capítulo de la misma carta representaba el Ayuntamiento que los conquistadores de esta provincia, andando en la guerra y pacificación de ella, tomaban algunos esclavos para su servicio y los quintaban (es decir, se regulaba el derecho del quinto a favor de la Real Hacienda), y después de quintados se les iban tales esclavos, y los conquistadores quedaban con estas deudas al Rey del dicho quinto, y como ni para pagarlo ni para remediarse de otros muchos gastos habían tenido hasta entonces ningún provecho, y algunos habían salido de esta tierra y otros muerto y otros estaban en ella, suplicaban al Rey que perdonara a los muertos dichas deudas, y a los vivos diera 
por libres de lo que de esto pudieran deber al Rey, para ayudar a restaurarse de lo que en la conquista de esta tierra habían perdido. 6

Esta representación es muy semejante a las que hicieron otros cabildos de Indias con motivo de la prohibición de la esclavitud de los naturales. Sin embargo, es de notar que los vecinos de Guatemala subrayan el carácter reciente de su conquista para diferenciarla de la te Nueva España y reforzar de esta suerte sus pretensiones ante la Corona.

Que éstas corrieron con suerte favorable lo dan a entender las cédulas reales que en seguida examinaremos. En la villa de Medina del Campo, a 20 de julio de 1532, dicen don Carlos y doña Juana al Adelantado don Pedro de Alvarado, gobernador de la provincia de Guatemala, y al licenciado Francisco Marroquín, protector de los indios, que bien saben como mandaron dar una carta firmada de la Emperatriz y Reina, en Madrid a 2 de agosto de 1530 (es decir, la prohibición que ya conocemos acerca de los esclavos de guerra y de rescate); pero ahora Gabriel de Cabrera, en nombre de la ciudad de Santiago y de las otras ciudades y villas de la provincia de Guatemala, hizo relación que si dicha provisión se hubiese de ejecutar, demás del notorio agravio y perjuicio que de ella redundaría a la población de la tierra y a los pobladores de ella, por quitarles y prohibir que no puedan rescatar ni contratar los esclavos que los caciques e indios tienen por esclavos, a los mismos indios se les seguiría mucho daño, por quitarles el beneficio que recibían en salir de poder de los caciques e indios que los tenían por esclavos, por el peligro en que estaban de ser sacrificados, demás que en venir a poder de los cristianos podrían ser instruídos y doctrinados en las cosas de la fe. El citado Cabrera pidió que se revocase dicha provisión y se diese licencia para rescatar los esclavos de la manera que antes se hacía. Visto en el Consejo de Indias y consultado con la Emperatriz y Reina, fué acordado que Alvarado y Ma-

6 Archivo General del Gobierno, Guatemala (en adelante AGG.), A 1. 2.5 Expe. diente 25235. Legajo 2833. Documento sin fecha. En la parte superior del folio 1 se lee a lápiz: 1580; pero el documento mismo no ofrece base para justificar esta data y por su contenido pienso que corresponde a la década de 1530 . Como guía para consultar los do. cumentos del Archivo citado me fué en extremo útil la obra de J. Joequín Pardo, Prontuario de Reales Cédulas. 1529-1599, Guatemala, 1941. 
rroquín, ambos a dos sin lo cometer a otra persona, hubiesen información y supiesen qué esclavos eran los que así los dichos caciques e indios tenían en su poder por esclavos, y los que constare que verda. deramente lo eran, los hiciesen herrar, y así herrados, de ahí en adelante pudiesen los vecinos y pobladores de la provincia, sin embargo de la provisión de 1530 , comprarlos y rescatarlos de los caciques e indios, con tanto que dichos esclavos no se pudiesen sacar de la provincia. Estando el Adelantado ausente de la gobernación, su Iugarteniente podría hacer juntamente con el Protector lo contenido en esta provisión. ${ }^{7}$

Esta reforma de la cédula prohibitiva de 1530 satisfacía los deseos de los españoles en cuanto al rescate de los esclavos indios; pero quedaba aún sin resolver el caso de los esclavos de guerra. De este otro aspecto se hizo cargo la cédula real dada en Belpuche, a 19 de marzo de 1533, a solicitud del mismo procurador Gabriel de Cabrera. Este hizo valer que había algunos caciques de guerra que siendo requeridos no querían estar debajo de la obediencia y señorío del Rey, ni admitir la predicación cristiana, antes hacian daño a los cristianos todas las veces que lo podian hacer. Pedía que se les pudiese hacer guerra y tomarlos como esclavos y como tales repartirlos entre las personas que los ganasen y prendiesen, sin embargo de cualquiera prohibición. Platicado en el Consejo de Indias, se manda al licenciado Francisco Marroquín, obispo de la provincia de Guatemala, y a don Pedro de Alvarado, gobernador, o a su alcalde mayor, que juntos, o el uno estando el otro ausente o impedido, vayan adonde estuvieren los indios alzados y les hagan el requerimiento que está acordado, que se les envía señalado de los del Consejo de Indias; y si por caso todos estuvieren ocu. pados o impedidos de manera que no puedan cómodamente ir, nombren en su lugar dos personas religiosas o clérigos sacerdotes de buena conciencia y confianza, en cuya presencia, el capitán que fuere haga dichos requerimientos por lenguas intérpretes fieles que se lo den bien a en.

7 AGG., Libro Cuarto de Reales Cédulas. A. 1. 2-4. 15752. Fol. 4. Esta cédula se encuentra también en el Archivo General de Indias (en adelante AGI.), Guatemala 393, lib. 1 , fol. 13 . 
tender, los cuales pasen ante escribano y testigos; y hechos dichos requerimientos, se han de ver y examinar por Marroquín y Alvarado, y si les pareciere que con justicia se puede hacer guerra, lo declararán así, y el Rey da licencia a cualesquier personas de esa tierra para que entonces puedan hacer dicha guerra y a los que en ella prendieren tomarlos por sus esclavos y como a tales venderlos, sin embargo de cualquier carta y provisión, que en cuanto a esto las deroga y anula, con tanto que no se puedan sacar los indios de esa provincia, so pena de la merced real y de diez mil maravedis para la cámara. ${ }^{8}$

De esta suerte, los conquistadores de Guatemala volvían a gozar del derecho de tener esclavos indios de rescate y de guerra como antes de la prohibición de 1530, salvo algunas modificaciones en cuanto a la forma.

La gente de México no obtuvo concesiones semejantes hasta que se dió otra cédula en Toledo, a 20 de febrero de 1534.9

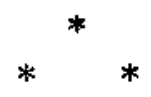

Las disposiciones reseñadas no pusieron término a la polémica en torno a la esclavitud de los indios. Había en España y las Indias una fuerte corriente de pensamiento que se oponía a ella, y la legislación tolerante de la Corte fué combatida con vigor.

Los oidores de México escribieron alarmados a la Emperatriz, el 11 de mayo de 1533, que les había llegado aviso sobre que se había concedido el hierro a Guatemala para que hubiera esclavos; no lo podían creer por el daño que se seguiría. ${ }^{10}$ El 5 de agosto ya tenían certidumbre de la novedad por carta que les había escrito el licenciado

- AGG., Libro Cuarto de Reales Cédulas. A. 1-2-4. 15752. Fol. 6v. En el fol. 7 y ss. viene la forma y orden del requerimiento que se ha de hacer a los indios alzados de la provincia de Guatemala, que es el conocido texto redactado por Palacios Rubios y usado en muchas conquistas de Indias. Cfr. S. Zavala. Las instituciones juridicas en la conquista de América, Madrid, 1935, pp. 286-288.

9 Colección de Documentos Inéditos de Ultramar (en adelante DIU.), Madrid, 1885.1925, X, 192 ss.

jo ACI., Papeles de Simancas, 58-5.8. Epistolario de Nueva España, cit., III, doc. 136. 
Marroquín, y repetían que era la perdición total de la provincia. ${ }^{11}$ El presidente de la Audiencia de México, Ramírez de Fuenleal, representó el día 8 que el hierro de los esclavos sería fuego que devastaría la tierra; como un índice de los excesos acogía el rumor de que ya valían los esclavos en Guatemala a dos pesos, cuando el año anterior costaban en la ciudad de México a cuarenta. ${ }^{12}$ Los franciscanos de México elevaron una hermosa protesta en la que decían:

"Oh católico Príncipe, y ése ¿es el galardón que de vuestras reales manos esperaban vuestros vasallos?; ¿y éste es el tesoro que la Igle sia esperaba de las ovejas a vos encomendadas?; no podemos alcanzar con qué espíritu fué movido el que tal relación fué a dar a vuestro Consejo para que tan gran crueldad concediese, ni podemos imaginar cuán perentorias fueron las razones de aquél que así pudiese conven. cer la sabiduría de tan claros varones como hay en vuestro alto Consejo para que tal cosa otorgasen".

A continuación sostenían que la concesión del hierro era contra la ley divina, la cual no consentía que los libres fuesen esclavizados; el Consejo podía decir que sólo consentía herrar a los esclavizados justamente, pero los frailes argüían que los españoles tenían sobrada codicia e importunaban a los caciques para que les rescataran esclavos a trueque del tributo que les habían de dar, y los caciques, por verse libres, entregaban maceguales (esto es, indios comunes) libres por esclavos; que la concesión era contra el oficio imperial, que consistía en amparar a la Iglesia y libertar a los cautivos injustamente; tam bién iba contra la condición con que fueron dadas las Indias por el pontífice (Alejandro VI) y contra toda ley de buena gobernación que quería que las tierras y reinos se conservasen y aumentasen; antes esperaban que el Rey mandase libertar a los esclavos que tenían los naturales, porque eran injustamente hechos, que no mandar herrar a otros indios de nuevo. ${ }^{13}$

11 Ibid., III, doc. 140 .

12 Ibid., III, doc. 141.

13 Academia de la Historia. Madrid. Colección Muñoz, LXXIX. M. Cuevas, Docu mentos inéditos del siglo XVI para la Historia de México, México, 1914, p. 13. La fecha del parecer es de julio de 1533 . Véase también J. A. Saco, Historia de la esclatisud de los indios del Nuevo Mundo, Habana, 1932, II, 181-183. 
En esta ocasión, tampoco faltó la voz vehemente de fray Bartolomé de las Casas, quien escribía a un "muy excelente señor", desde la ciudad de Granada de la provincia de Nicaragua, a 15 de octubre de 1535 : "Una de las vías inicuas con que la gente de esta provincia e reino de Nicaragua en tan breve tiempo ha sido miserablemente asolada, ha sido la tríste licencia que ese Real Consejo ha dado para que puedan hacer esclavos". Se muestra asombrado de "como puede tanto la malicia de los que tal informan, que baste a engañar a una tan egregia y admirable sabiduría..." Afirma que no hay ningún esclavo indio en las Indias que justamente lo sea o lo haya sido. Ahora está por averiguar que ninguna guerra, desde que las Indias se descubrieron hasta hoy, ha habido justa de parte de los cristianos. Lo que dicen los españoles acerca de que se les dé licencia para hacer esclavos a solos los que los mismos indios tienen por esclavos, es diabólico, porque so color de uno que los indios tienen, hacen ellos esclavos a la mitad y las dos partes de los vasallos del cacique. Así han llevado de dos años acá más de 12,000 ánimas al Perú y "todos son muertos" y no escapó alguno, y éstos están escritos en los libros del Rey. Añade que se han llevado de Nicaragua a Panamá más de 25,000 almas y "todos son muertos". Y al Perú, antes de los años dichos, más de otros 15,000 y "todos son muertos". No va nao de estos puertos que no lleve más de 300 ánimas y "todos" mueren antes de llegar al Perú, de sed y hambre. No hay derecho natural, humano o divino en que esto pueda fundarse. Estos infieles no son moros que resisten la fe, sino que la reciben; ni detienen tierras ajenas, sino suyas; no infestan a los cristianos, sino que éstos los han invadido y les hacen daños y ponen en cautiverio. Menciona aquí al canonista Ostiense "que más duramente habló contra los moros", pero no contra los indios, y sin embargo él reconoce que si los infieles acatan la autoridad de la Iglesia no deben perder sus bienes. Y Ostiense es singular, porque Inocencio, y los que después de él vinieron, que todos le siguen, tiene opinión contraria y está fundada en verdadera teología y en la suave ley de Cristo y piadosa costumbre de la Iglesia. Los indios "son lo que fuimos en 
España antes que nos convirtiesen los discípulos de Santiago, y aun harto mejores en esto y más aparejados para recibir la fe que nosotros". Pide que se quite el hierro que ahora vino concedido para herrar esclavos, porque hacen esclavos a chicos y grandes y los llevan a vender a Panamá y al Perú. Y no se olvide la gobernación de Guatemala, que se asuela y destruye. El y sus compañeros, para convertir infieles, "querríamos estar donde no nos estorbasen cristianos". Y termina con una hiriente alusión a "aquella fiera bestia de Lutero". ${ }^{14}$

Es posible que a estas censuras se deba la actitud vacilante que refleja la cédula que dió la Reina en Valladolid, a 9 de septiembre de 1536. Encarga al gobernador y juez de residencia que fuere de la provincia de Guatemala - lo era el licenciado Alonso de Maldonado desde el 10 de mayo de 1536 - que entienda en pacificar y poblar la parte restante de la tierra que está por conquistar, lo cual hará con parecer del obispo de esa provincia, quien tendrá el hierro con que se han de herrar los indios que se tomen y cautiven en justa guerra; en hacer dicha conquista y rescate se guardarán las ordenanzas dadas y las que se den. Y el gobernador no consentirá que ningún indio se haga esclavo por rescate, debiendo matricularse los que al presente hay en la provincia; y prohibirá que los caciques e indios puedan hacer entre sí esclavos por ninguna causa, y para ello les pondrá las penas que le parezcan. 15

De acuerdo con esta cédula, subsiste el derecho de esclavitud por guerra y el uso del hierro, si bien se toma la precaución de que lo guarde el obispo; en cambio, se desautoriza el derecho de esclavitud por rescate, quedando tan sólo en uso los esclavos de esta clase existentes en aquel momento y registrados en la matrícula.

Sobre el aspecto particular de la saca o extracción de los indios, la Emperatriz dirigió una cédula al gobernador de la provincia de $\mathrm{Hi}$ gueras y Cabo de Honduras, fechada en Valladolid el 29 de enero de 1538, en la que decía haber sido informada que se sacaban muchos

14 B. M. Bierman, "Zwei Briefe von Fray Bartolomé de las Casas, 1534-1535", en Archivum Fratrum Praedicatorum, Roma, IV, 1934, pp. 211 y ss.

is AGI., Guatemala 393, Lib. I, Fol. 178 v. 
indios esclavos de esta provincia, asi para el Perú y Guatemala como para otras partes, y que demás del daño que recibía la provincia en haberse disminuido los naturales de ella, los indios que así sacaban morían por las mudanzas de las tierras y gran descontento que tenían. La voluntad real era que los indios de esas partes, de tal manera sirvieran a los españoles que los iban a conquistar y poblar, que ellos vivieran y se conservaran, y viviendo pudieran venir en reconocimiento de Dios y de la fe católica, y que anticipándoles la muerte no perdieran tan grande beneficio. En consecuencia, la Emperatriz mandaba que el gobernador hiciera pregonar en los pueblos de cristianos de esa provincia que ninguno sacara indio ni india esclava de ella, si no fuere uno o dos para su servicio, so pena de perdimiento de bienes y destierro perpetuo de ella. ${ }^{16}$

La Corona dió posteriormente otras disposiciones a fin de reforzar el propósito contrario a la esclavitud por rescate. Don Carlos y dona Juana, en cédula de Toledo de 31 de enero de 1539, manifiestan ser informados que a causa de estar permitido que los españoles que han ido a conquistar y poblar la provincia de Guatemala pudiesen rescatar y comprar de los caciques y principales y otras personas naturales de dicha tierra los indios que les son sujetos y tienen por esclavos, ha venido en tanto exceso que se han hecho muchos esclavos, a cuya causa no son tan bien tratados como convendría, porque les dan trabajos demasiados y les hacen otras premias; los principales indios hacen esclavos por causas livianas. Don Carlos y doña Juana mandan, por lo tanto, que en adelante, por ninguna vía ni forma, ningún español sea osado de rescatar ni comprar de dichos caciques y principales $y$ otras personas naturales de la tierra que estuvieren de paz y en sujeción de la Corona, los indios que ellos tienen sujetos y por sus esclavos; y si algún español los rescata, los ha de perder y se darán por libres, y perderá

16 AGG., A. 1. 2-4. 2195. 218v. Es de notar que en Segovia, a 7 de agosto de 1565, el Rey mandó al virrey, presidente y oidores de la Audiencia de México y al gobemador de la provincia de Guatemala, que dicha cédula se guardara en todas las ciudades, villa y lugares de esta última provincía. 
lo que le hubieren costado. Esta cédula se pregonó en Santiago de Guatemala el 28 de julio de 1539. 17

Además de privar a los españoles del derecho de rescatar los indios esclavos, la Corona tomó medidas complementarias que afectaban a la prerrogativa de los indios para hacer esclavos. En efecto, en Toledo a 31 de enero de 1539, los mismos don Carlos y doña Juana dicen haber sido informados que los caciques y principales de la provincia de Guatemala tenian de costumbre hacer y tomar por esclavos de los naturales que les eran sujetos por muy livianas cosas y con mucha facilidad y los vendían y trataban como tales a los españoles que habían ido a conquistar y poblar dicha tierra, y ellos entre sí. Y como quiera que siendo informados los propios don Carlos y doña Juana del exceso que en esto habia habido, por una provisión de la data de ésta habían prohibido que por ninguna vía ningún español pudiese de aqui adelante comprar ni haber por vía de rescate ni en otra manera, esclavo alguno de los dichos indios, todavía, por excusar cosa tan mal hecha y los inconvenientes que de la dicha costumbre sucedían, visto en el Consejo de las Indias, fué acordado dar esta carta, por la cual mandan y defienden firmemente "que agora ni de aquí adelante, ninguno de los dichos caciques ni principales ni otro indio alguno puedan hacer ni hagan esclavos indios algunos ni los vender ni rescatar a persona alguna, y si alguno hicieren, por la presente los damos por libres para que hagan de sí lo que quisieren y por bien tuvieren, sin que por persona alguna les sea puesto en ello embargo ni impedimento alguno, por cuanto siendo como son nuestros súbditos y vasallos son obligados en esto a guardar y vivir por las leyes destos nuestros reinos". Se manda pregonar en la ciudad de Santiago de Guatemala y en las otras ciudades y lugares de Nueva España. En efecto, se pregonó en la capital guatemalteca el 28 de julio de 1539, por mandado del licenciado Alonso de Maldonado. ${ }^{18}$

17 AGG., Libro Cuarto de Reales Cédulas. A. 1. 2-4. 15752. Fol. 42v.

$1 B$ ACG., Libro Cuarto de Reales Cédulas. A. 1. 24. 15752. Fol. 45v. Hay otro tex to igual en A. 1. 2-4. 2195. 188. En ambos casos la cédula aparece fechada en Toledo, a 31 de enero de 1538; en ambos, también, la fecha del pregón es 28 de julio de 1539 . Se habrá observado que esta cédula que prohibe a los indios el hacer esclavos expresa que es 
Si bien eran terminantes las disposiciones que ponían el rescate de esclavos indios fuera de la ley en Guatemala, la esclavitud por guerra no había sido desautorizada (de acuerdo con los elementos de que disponemos) con posterioridad a la cédula de Belpuche de 19 de marzo de 1533, que, según se recordará, permitía vender los esclavos tomados en las acciones emprendidas con la debida aprobación de las autoridades. Ya mencionamos también la cédula de Valladolid de 9 de septiem. bre de 1536, que mantenía la esclavitud por guerra al mismo tiempo que ponía cortapisas a la de rescate.

Las famosas Leyes Nuevas promulgadas en Barcelona el 20 de Noviembre de 1542 vinieron a modificar esta situación jurídica, pues un capítulo de ellas mandaba que, en adelante:

"por ninguna causa de guerra ni otra alguna, aunque sea so título de rebelión, ni por rescate, ni de otra manera, no se pueda hacer esclavo indio alguno: y queremos que sean tratados como vasallos nues. tros de la Corona de Castilla, pues lo son"

La prohibición comprendía pues, indistintamente, cualquier caso futuro de esclavitud de indios, ya fuese por guerra o por rescate. Otro capítulo se hacía cargo de los esclavos existentes al darse las Leyes y disponía que las Audiencias pusiesen en libertad, sumariamente, a los hechos contra razón y derecho y contra las provisiones e instrucciones dadas, en caso que los amos no mostraran título de como los poseían legítimamente. Habría personas encargadas de solicitar la libertad de los indios ante las Audiencias. ${ }^{19}$

En relación con el envío de las Leyes Nuevas a Guatemala es de tener en cuenta una cédula que dirigió el Rey, desde Barcelona a $I$ de

dada en la misma data en que se expide la que prohibe a los españoles rescatar los esclavos. Por esta razón y por la fecha del pregón creo que la cédula relativa a los índios es de 1539 y no de 1538, como he corregido al hacer uso de ella en el texto del presente estudio. No me siento inclinado, mientras no aparezca prueba suficiente para ello, con. siderar buena la fecha de 1538 para ambas cédulas de Toledo, que seria otra manera de coordinar los documentos. En todo caso, parece fuera de duda que el pregón tuvo lugar en julio de 1539 .

19 Véase la edición facsimilar de la Facultad de Filosofía de la Universidad de Buenos Aires, 1923. 
mayo de 1543, a fray Pedro de Angulo, que ejercía el vicariato de la orden de Santo Domingo en esa provincia, anunciándole que le mandaba ejemplares impresos de las ordenanzas para que las viera y repartiera entre los monasterios y religiosos, con objeto de que las explicasen a los naturales, encargándole mucho el cumplimiento de ellas y que avisara de cualquier infracción. ${ }^{20}$

Los vecinos de Guatemala, a 10 de septiembre de 1543 , ya tenían noticias de la novedad y escribían al Rey: "estamos tan escandalizados como si nos enviara a mandar cortar las cabezas". Creían que Las Casas había sido parte para esta sentencia tan cruel y le censuraban vivamente. Recordaban al Rey que le habian servido con vidas y haciendas, sin interesar su majestad un peso de oro, $y$ pedían que se les oyera, añadiendo: "Páguenos vuestra majestad lo que nos debe y háganos grandes mercedes". 21

El 12 de octubre de 1543, a propuesta del síndico Alfonso Pérez, acordó el Ayuntamiento enviar un procurador a la Corte para solicitar la derogación de las ordenanzas. El 23 del mismo mes se encargó la comisión al gobernador Maldonado -quien de nuevo ejercía el cargo desde el 17 de mayo de 1542, habiendo ocurrido la muerte del Adelantado don Pedro de Alvarado el 4 de julio de 1541—, pero se excusó, pues "había de ejecutar lo que su majestad mandara y que en todo lo demás habría de hacer lo que conviniera a su servicio". ${ }^{22}$

El 14 de noviembre fueron designados procuradores el obispo Marroquín y Gabriel de Cabrera, que tampoco aceptaron. ${ }^{23}$

A principios del año 1544 llegaron los oidores Herrera, Ramírez y Rogel. El 16 de mayo quedó instalada la Audiencia de los Confines en la ciudad de Gracias. ${ }^{24}$ Y el 30 de mayo, en la ciudad de San-

20 Villacorta, Prehistoria..., p. 452, quien toma el dato de la Colección de Documentos lnéditos del Archivo del Ayuntamiento de Guatemala, formada por Arévalo, 1857, edición de la Sociedad de Geografia e Historia, Guatemala, 1935, p. 307.

21 Villacorta, Prehistoria..., pp. 453-455.

22 Villacorta, op. cit., p. 456 y J. J. Pardo, E/emérides de la Antigua Guatemala, 154I-1779, Guatemala, 1944, p. 4.

23 Villacorta, op. cit., p. 456.

24 Villacorta, op. cit., p. 459. 
tiago, fueron pregonadas por voz de Cristóbal de Villatoro las ordenanzas para el buen gobierno. ${ }^{25}$

¿Hubo algún indicio de que las Leyes Nuevas se cumplirían en lo que respecta a la esclavitud? Así parece sugerirlo una provisión real dada por la Audiencia que residía en la ciudad de Gracias a Dios, a 11 de agosto de 1544, en nombre de don Carlos y doña Juana, y dirigida a los gobernadores y justicias de las provincias sujetas a la misma Audiencia. En ella se manifestaba que convenía al servicio de la Corona que se declarasen y manifestasen todos los esclavos indios que había en esas ciudades, villas y lugares, y lo que cada uno tenía, así hombres como mujeres, y que se hiciese registro y matrícula de ellos. Por eso mandaba la Audiencia que todos los esclavos naturales de estas partes se manifestasen, declarando con juramento cada persona la cantidad que tenía y en qué partes, minas y granjerías, y lo demás que para este efecto pareciera ser necesario; la declaración se asentaría en un libro o manual ante escribano; las justicias fijarían término para la manifestación, so pena de que los dueños perdiesen los esclavos que dejaran de manifestar; a la Audiencia se enviaría el traslado del registro y matrícula de los esclavos para que supiera la cantidad que habia y proveyera lo que al servicio real conviniera. ${ }^{26}$

Estas órdenes de la Audiencia de Gracias a Dios eran más bien de carácter preparatorio y no entrañaban aún el cumplimiento estricto del capítulo de las Leyes Nuevas, que según sabemos mandaba averiguar la justicia con que habían sido hechos los esclavos existentes, con objeto de poner en libertad a los que no estuvieran comprendidos bajo la titulación legítima. Pero la sociedad colonial había previsto la amenaza que significaban las nuevas ordenanzas para sus intereses, y a las primeras medidas de defensa añadió otras más enérgicas.

EI 31 de agosto de 1544, la propia Audiencia, presidida por el licenciado Alonso de Maldonado, avisó al Emperador que el Cabildo de Guatemala había apelado de las Leyes Nuevas, incluyendo el capítulo de los esclavos, porque los conquistadores no podían exhibir otro

25 Pardo, Efemérides..., cit., p. 5.

26 AGG. A. 1-2-4. 2196. 168. 
título que el de haber tomado a los indios en la guerra y que fueron herrados por orden de los capitanes y gobernadores. Tampoco era fácil al que poseía esclavos por compra demostrar que los tenía legítimamente. ${ }^{27}$

El 4 de junio de 1545, desde Santiago de Guatemala, escribía el obispo Marroquín al Emperador:

"Cuando el Audiencia llegó, ya todos estaban alterados y conmovidos con las nuevas ordenanzas y leyes, porque como a todos les va mucho interés, hase sentido mucho. Ya sentada el Audiencia, de todas partes acudieron para pedir y suplicar, y a todos se respondió como mejor pareció que convenía; y sus suplicaciones y respuestas todo va cerrado y sellado, a que me remito. Sé decir a vuestra majestad que tiene muy leales vasallos, y que desean acertar en servicio de Dios y de su Rey".

Hace ver que esta cosa es muy ardua. Concede a los del Consejo mucha ciencia y parte de experiencia, "pero acá hay mucha más experiencia". Mucho conviene al Rey dar asiento en esta tierra de una vez para siempre y hacer merced a sus vasallos. El remedio es que se cometa esto a personas prominentes de Indias, y lo que determinen, el Rey lo afirme. ${ }^{28}$

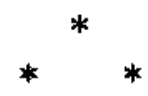

La liberación de los esclavos en Guatemala no recibió, al parecer, nuevo impulso hasta que el licenciado Alonso López de Cerrato tomó posesión del cargo de presidente de la Audiencia de los Confines el 26 de mayo de 1548, sustituyendo al licenciado Alonso de Maldonado. Pero durante aquellos años de espera habían ocurrido hechos de suma importancia en las Antillas y en Nueva España, y se habían elevado a la Corte consultas, de cuya resolución dependía la suerte de los indios sujetos a esclavitud.

27 Ms. en Municipalidad de Guatemala. Libro de consultas a Su Majestad, cit. por L. B. Simpson, Studies in the Administration of the Indians in New Spain, Berkeley, 1940, (Ibero-Americana 16), p. 5.

28 Villacorta, Prehistoria..., pp. 459-460. 
Cerrato ya poseia alguna experiencia con respecto a la aplicación de las Leyes Nuevas cuando llegó a la presidencia de los Confines. En efecto, fray Bartolomé de las Casas avisa a la Corte, desde la ciudad de Santo Domingo de la Isla Española, el 15 de septiembre de 1544, que el licenciado Cerrato "ha libertado después que vino algunos indios que tenían por esclavos, conviene a saber, los que no tenian hierro: dijome que había consultado a vuestra alteza sobre los que tienen hierro o están herrados con hierro que dicen que es dado por su majestad". Las Casas sostiene que ningún indio es esclavo justamente: "la razón es porque causa ninguna justa no ha habido para hacerles guerra, ni tampoco ha habido autoridad de su majestad ni de los reyes pasados, porque dado que en algunos casos los reyes dieron, a falsas informaciones engañados y lo mismo su majestad, licencia para hacer guerra con ciertas limitaciones y condiciones, vuestra alteza sea cierto que hasta hoy nunca se guardó carta ni mandamiento y provisión ni instrucción cerca desto". Pedía que de una vez se declarase que todos los indios, herrados y por herrar, eran libres. ${ }^{29}$

Habia surgido, por lo tanto, un problema de interpretación de las Leyes Nuevas; pues éstas, al mandar que se pusieran en libertad los indios cuando los amos no tuvieran un título de posesión legítima, no habían aclarado si el hierro en el cuerpo del esclavo podía considerarse como prueba bastante. De la interpretación amplia o restringida de esa prueba de posesión dependería el alcance que iba a tener en la práctica la nueva ley.

Por fuente ajena a Las Casas consta que la Audiencia de la Isla Española, al recibir las ordenanzas de 1542, mandó traer todos los indios esclavos para examinar su situación, y entre tanto prohibió sacarlos y enajenarlos como era costumbre; tampoco consintió que se herrasen hasta que concluyera el examen de los títulos. Estas medidas se sintieron mucho y el cabildo de la ciudad representó que los esclavos indios eran poseídos de buena fe y herrados en el rostro con el hierro de su majestad y que ése era título bastante y existía costumbre

\footnotetext{
${ }^{29}$ Academia de la Historia. Madrid. Colección Muñoz, t. LXXXIII. Copia moderna en la Biblioteca del Congreso, Wáshington, Mss. America. Spanish Colonies. Item 4. Handbook, 1918 , p. 19.
} 
sobre el particular desde el descubrimiento de las Indias; a continuación suplicó de las ordenanzas. La Audiencia prosiguió el examen que había emprendido. Cuando llegó a España el informe relativo a estos acontecimientos, el Príncipe hizo enviar una cédula a dicha Audiencia en abril de 1545, la cual se extendió a Nueva España en 28 de octubre de 1548, disponiendo:

"Lo que cuanto a los esclavos hechos por vía de guerra acá parece debéis hacer, es, que ante todas cosas, sin esperar a más probanza y sin haber otro más título, que sin embargo de cualesquier posesiones que haya de servidumbre ni que estén herrados, pronunciéis por libres todas las mujeres de cualquiera edad y todos los varones niños que eran de catorce años abajo al tiempo que los cogieron y que hayan sido cogidos en cualquiera guerra, entradas o rancherías que se hayan fecho en tierras de indios amigos o enemigos, porque éstos no se pudieron hacer esclavos aunque fuese por ocasión de rebelión; y a los que se hubieren hecho esclavos en guerra, que no sean de los susodichos, si el poseedor no lo probare que el indio que tiene por esclavo fué habido en guerra justa y que se guardó y cumplió en ella la diligencia y forma debida, darlos heis por libres, aunque no se pruebe por los indios cosa alguna, de manera que carguéis la probanza al poseedor y no a los indios, aunque estén herrados y tengan carta de compra u otros títulos los poseedores de ellos, porque estos tales, por la presunción que tienen de libertad en su favor, son libres como vasallos de su majestad; y si en estos indios, conforme a esto, hubiere algunos que del quinto de su majestad se hubieren vendido, y cobrado el precio sus Oficiales, y constandoos que se hizo cargo de ello en sus libros, haréis justicia llamada la parte del fiscal, y averiguado esto, proveeréis que de la hacienda de su majestad se vuelva a la parte lo que conforme a justicia su majestad tuviere obligación de pagar. $\mathrm{Y}$ en cuanto a todos los demás que no fueron esclavos por vía de guerra, que se prendieron por otras vías y pareciere ser esclavos y ellos de posesión de esclavos reclamaren en libertad, llamadas y oídas las partes, haréis sobre ello brevemente justicia, según halláredes por derecho y leyes de estos rei- 
nos, guardando asimismo la ley por su majestad últimamente hecha para esas partes cerca de los dichos esclavos". 30

Esta respuesta no implicaba la libertad automática de todos los indios esclavos, como quería Las Casas; pero quedaba aclarado que el hierro por sí solo no era título suficiente de esclavitud, y como la prueba que se exigía acerca de la legitimidad de la servidumbre era difícil y recaía sobre el amo, podia anticiparse que buen número de indios quedarían amparados por la ley. Así ocurrió en las Antillas, llegándose a estimar que la prueba que pedía la ley nueva era imposible y que debía entenderse que la voluntad real era conceder la libertad a todos. 31

Tampoco era indiferente para el porvenir institucional de Guatemala lo que había ocurrido en Nueva España durante los años inmediatos siguientes a la promulgación de las Leyes Nuevas.

Las Casas llegó a su obispado de Chiapa y se reservó la absolución de ciertos casos de conciencia y por esta vía espiritual quiso imponer la libertad total de los esclavos. Los vecinos se alteraron, pero creyeron que la idea del Obispo era atraerlos a la buena obra y no efectuarla; algunos libertaron a sus indios con la condición de que les ayudaran a terminar ciertas casas comenzadas. El Obispo no transigió. Los vecinos lograron que los absolviera el Deán y se produjo un serio conflicto con amenazas y vías de hecho. 32

Con este motivo comentaba el franciscano Motolinia, opositor de Las Casas, que fray Domingo de Betanzos hubo de escribir al inquieto obispo de Chiapa "que las ovejas había vuelto cabrones, y de buen carretero, echó el carro delante y los bueyes detrás". 33

30 Diego de Encinas, Provisiones... Madrid, 1596, IV, 370-371 y 372.373. También en Archivo Histórico Nacional. Madrid. Cedulario Indico, tomo $\mathrm{X}$, fol. $325 \mathrm{~b}, \mathrm{n}$. 557, En este último lugar lleva fecha de 14 de enero de 1549, misma que da Puga, Protisiones..., México, 1879, II, 11-12. El texto relativo a la Isla Española se encuentra en Encinas, op. cit., IV, 371-372 y DIU., XXI, 174, n. 31 .

31 Ofrezco otros datos sobre las Antillas en mi estudio "Los trabajadores antillanos en el siglo XVI", en Revista de Historia de América, México, 1938, Núm. 2, pp. 36-39.

32 Colección de Documentos Inéditos de Indias, (en adelante DII.) Madrid, 1864-1889, VII, 156: "Relación de la entrada de Fray Bartolomé de Las Casas en Cibdad Real e su conducta con los indios esclavos".

33 Ibid., VII, 264. 
El visitador de Nueva España, Tello de Sandoval, refería al príncipe don Felipe el mismo episodio en carta de 9 de septiembre de 1545:

"Fray Bartolomé de Las Casas, obispo de Chiapa, tomó puerio en esta Nueva España en Campeche que es en la provincia de Yucatán y quisiera ser luego recibido por obispo en la dicha provincia y presentó sus bulas y provisiones en la ciudad de Mérida y no lo quisieron admitir, de que fué muy desabrido: de allí fué a Ciudad Real que es cabeza de la provincia de Chiapa donde le recibieron muy bien y después de recibido ordenó ciertas cosas de que hubo algún escándalo, la memoria dello envío a vuestra alteza: agora me han dicho que un Mazariegos vecino de la dicha ciudad lo quiso matar y que le huyó por encima de las paredes y se fué al Audiencia de Gracias a Dios, donde dicen que agora está: he sabido que muchos de los vecinos del pueblo están descomulgados y por confesar por causa de lo que el dicho obispo nuevamente proveyó: necesidad hay en esta tierra de tener paciencia y de hacer las cosas con sabor y poco a poco y al fin se viene hacer lo que conviene". 34

A esta tormenta regional siguió la junta de letrados en México, año de 1546, donde Las Casas volvió a defender el criterio de que no había esclavos indios bien hechos y que la libertad debía alcanzar a todos. Y siguió viaje a España para insistir en esta tesis que consideraba ajustada al espíritu de las Leyes Nuevas. Asimismo mantuvo la misma doctrina en su famoso tratado "sobre la materia de los indios que se han hecho esclavos", impreso en Sevilla en 1552. 35

En Nueva España, después de algunas vacilaciones, la Audiencia se inclinó cada vez más a favor de la política de libertad y, en la década inmediata siguiente al 1550, amparó a considerable número de esclavos. Pero ésta es materia que trataré en otra obra y que no debe distraernos de la narración tocante a Guatemala.

Veamos cuáles eran las órdenes que debían regular la conducta del licenciado Cerrato cuando pasó de la Isla Española a la presidencia de la Audiencia de los Confines.

34 AGI. Papeles de Simancas, 58-5-8. Epistolario de Nueva España, IV, doc. 246.

35 El impresor fué Sebastián Trugillo. Otra edición en Biblioteca de Autores Espa* ñoles, LXV, 208-226. 
El Príncipe habia dado una cédula en Segovia, a 25 de junio de 1548, en la que hacía saber a Cerrato que tenía relación acerca de que de la provincia de Nicaragua se habían sacado muchos indios para otras partes, así hechos esclavos injustamente como naborias e indios libres, contra lo proveído, y que convenía mandar con respecto a los indios que hubiesen sido herrados por esclavos con el hierro de su majestad, del cual se había usado mal, que fuese una persona a examinar y ver cómo se habían hecho esclavos, y hallando ser contra las provisiones dadas y nuevas leyes hechas, los diese por libres conforme a la cédula que se había dado cerca de los indios de la Isla Española, y los que fuesen de la provincia de Nicaragua se restituyesen a ella; y que los otros indios que no tuviesen hierro, sin dilación ni audiencia, fuesen luego puestos en libertad y restituidos a dicha provincia como personas lihres. Visto en el Consejo de Indias, se manda a Cerrato que vea lo susodicho y conforme a las nuevas leyes y a la cédula que de suso se hace mención, que para el propio Cerrato se dió, provea lo que viere que conviene, de manera que dichos indios sean desagraviados y puestos en libertad los que no fueren esclavos, y si los tales indios estuvieren muy distantes de esa Audiencia, en parte donde Cerrato en persona no pueda entender en ello, lo remita a persona de letras y confianza para que haga dichos procesos y los lleve ante Cerrato para que los sentencie por derecho. $\mathrm{Y}$ en lo que toca a los otros indios que no estuvieren herrados con hierro del rey y constare ser de Nicaragua, haciendo las diligencias que a Cerrato pareciere y queriendo ellos volver de su voluntad a dicha provincia, provea que se lleven a ella sin dilación y se presenten ante el Obispo para que éste tenga cuidado de mirar por su buen tratamiento y dar orden como sean instruídos en las cosas de la fe. ${ }^{36}$

Esta cédula, en consecuencia, extendía a la Audiencia de los Confines la vigencia de la provisión de 1545 enviada a la Isla Española; en tal virtud, el hierro no sería considerado por sí solo prueba dé la legitimidad de la servidumbre, pues como se había representado al

36 AGG., A. 1. 23. 1511. 72 . 
Príncipe, pudo usarse indebidamente de la marca real. La libertad de los indios que no habían sido señalados con el hierro se concedía sin traba, pero nótese que el regreso de los mismos a la provincia de origen quedaba pendiente de su voluntad.

Cerrato había escrito al Príncipe desde Santo Domingo, en 17 y 26 de abril de 1548, cuando se disponía a partir para la Audiencia de los Confines, que del Nombre de Dios le informaban que los indios e indias se vendían tan públicamente como los negros de Guinea, especialmente las mujeres, y que aunque Cerrato estaba satisfecho de lo que debía hacer en ello, por cumplir con las gentes suplicaba se le mandara lo que debia hacer. La respuesta del Príncipe, dada en Valladolid a 14 de julio de 1548, fué en el sentido de que Cerrato guardara las leyes por el Emperador hechas (es decir, las de Barcelona de 1542) cerca de la libertad de los indios y que no consintiera ir contra su tenor. 37

Así es que Cerrato pasaba a la Audiencia de los Confines, no sólo con la experiencia de lo que había ocurrido en la Isla Española, sino también con autorización para aplicar la cédula aclaratoria de 1545 y una recomendación expresa acerca de que se guardaran las Leyes Nuevas en cuanto a la libertad de los indios.

Todavia el 1 de septiembre de 1548, desde Valladolid, escribe el Príncipe a Cerrato, que ha sido informado que algunos vecinos de las provincias sujetas a la Audiencia de los Confines, contra lo mandado, llevan indias a vender a Nombre de Dios y otras partes de las Indias, no lo pudiendo ni debiendo hacer, por ser contra las Nuevas Leyes hechas por su majestad y provisiones cerca de ello dadas y en deservicio de Dios y daño y perjuicio de los indios. Conviene que lo susodicho se excuse y que los que han sacado dichos indios contra lo mandado sean castigados, por lo cual manda el Príncipe a Cerrato que se informe qué indios se han sacado de las provincias sujetas a esa Audiencia para llevarlos a otras partes a vender, y a los que en ello hallare culpados los castigue conforme a justicia, y los indios que se

37 AGG., A. 23. 1511. 74. 
hubieren vendido y constare a Cerrato que son libres y estuvieron (sic) en las provincias sujetas a esa Audiencia, los ponga en libertad para que como personas libres la consigan, y en adelante no consienta ni dé lugar a que de esas provincias se saque indio alguno, y provea que cerca de ello se guarden las Nuevas Leyes y provisiones por su majestad dadas y que contra ellas no se vaya ni pase en manera alguna, y ejecute en las personas y bienes de los que contra ellas fueren las penas en que hubieren incurrido. ${ }^{38}$

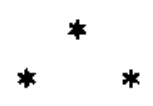

Examinada la legislación en torno a la actuación de Cerrato en la Audiencia de los Confines, réstanos ver cuál fué ésta en lo que toca a la libertad de los esclavos indios y cómo reaccionaron los po. bladores de las provincias sujetas a esa jurisdicción.

Por carta de 21 de mayo de 1549, Cerrato y los oidores informaron a la Corte que habían mudado la sede de la Audiencia, de la ciudad de Gracias a Dios a la de Guatemala. En el camino hicieron la tasación de los indios de San Salvador y hallaron allí muchos in. dios $\mathrm{e}$ indias que se tenían por esclavos, $\mathrm{y}$ conforme a la ley que sobre ello dispone, los dieron a todos por libres, llamadas y oídas las partes a quienes tocaba, y lo mismo hicieron en la ciudad de Santiago. Añadían que se habían hecho las tasaciones de los tributos que los indios habían de dar, y entendían en castigar a algunos encomenderos por malos tratamientos que habían hecho a los indios y tributos demasiados que les llevaban, en lo cual estaban culpados los más, y por ello eran privados de los indios, y que las tasaciones se acabarían de hacer muy en breve y se pondría todo en orden. Maximiliano, estando en Valladolid, a 7 de julio de 1550, acogió con beneplácito estas noticias de la Audiencia y le encargó que hiciera lo susodicho con cuidado y diligencia. Además escribía:

38 AGI., Guatemala 402, lib. 2, fol. 250 v. Al margen: "Sobre lo de los yndios que se venden". Un extracto de esta cédula en $D I U .$, XXI, 184, n. 89. 
"En lo que decís que las provisiones que Nos habemos mandado enviar a esa Audiencia para que no se carguen los indios, ni se alquilen, ni se traigan en minas ningunos indios de encomienda y se pongan en libertad los que no son bien hechos esclavos, se guardan en esa Audiencia al pie de la letra y que los vecinos de esa tierra os dan muy en cara con que esto ni cosa de ello no se guarda en el Audiencia de México y que les parece que les hacéis muy grande agravio, lo mismo que en esto está proveído para esa Audiencia está ordenado para la Audiencia de la dicha Nueva España y está mandado que se guarde y cumpla y así se hará". ${ }^{39}$

Además del anterior informe de índole oficial, hay otras fuentes que comprueban el alcance de la reforma emprendida por el presidente y los oidores.

En la gobernación de Guatemala, Diego de Salamanca poseía por compra hecha a los Oficiales Reales y a otras personas, diecisiete o dieciocho esclavos indios, que le ganaban en las minas y otras granjerías más de mil castellanos al año. El licenciado Cerrato le quitó los esclavos sin mandarle pagar cosa alguna de lo que le habían costado, ni compensarle de lo que ganaba con ellos. El vecino Bartolomé Díez perdió también sus esclavos, como los demás pobladores. El cronista Bernal Díaz refería que, en cumplimiento de las ordenanzas, el presidente de la Audiencia dió libertad a los esclavos que tenían en la cara el hierro de su majestad y lo hizo sin proceso y sin indemnizar a los españoles. ${ }^{40}$

Sobre esta materia escribió el comisario franciscano fray Francisco de Bustamante un extenso informe al Rey, fechado en Guatemala el 22 de marzo de 1551. Distinguía cuatro maneras de esclavos: a) los que servian en las minas; $b$ ) los de las milpas; $c$ ) los empleados por españoles no oficiales; y $d$ ) los que tenían los españoles oficiales o artesanos. Comentaba que se quitaron los esclavos a los españoles y se dejaron a los indios, cuando muchos de los poseídos por los españoles

39 AGG., A, 1. 23. 1511, 143.

40 "Información de Diego de Salamanca, uno de los conquistadores de Nueva España, adonde pasó con Pánfilo de Narváez". AGI., Simancas, 59-6-10. Copia en el Museo Nácional de México, Colección Paso y Troncoso, "Méritos y Servicios", carpeta V. 
los habían comprado de los indios. Bustamante aconsejó al licenciado Cerrato que para libertar a los esclavos de las minas fijara un año o dos, para que en este tiempo los mineros se proveyesen de negros, y que, durante tal plazo, los indios fuesen pagados de sus servicios y bien tratados y que no se ocupasen en los trabajos de peligro. En cuanto a los indios de las milpas, pensaba Bustamante que el amo les daba tierras para que labrasen y a veces casa, y trabajaban varios días de la semana para sí y otros para el amo; por esto dijo al licenciado Cerrato que eran como los renteros de España y que no era esclavonia y que podía moderar los días que trabajaban para los amos si eran muchos, pero no quitarlos a éstos, porque del maíz y trigo que estos indios cultivaban se proveía la ciudad. Bustamante admitió que los de la tercera categoría, o sea, los que servían a los españoles en casas o haciendas fuesen libertados y que se les pagase su trabajo, tasándolo la Audiencia, y que por entonces sirviesen a los mismos amos, y si en adelante los maltrataban, que se les quitasen y fuesen adonde quisiesen; razonaba que eran indios acostumbrados ya a los servicios de la casa y que estaban con sus mujeres e hijos bien tratados; si se quitaban y para servir en las casas de los españoles se llamaban indios de los pueblos comarcanos, sería mayor el daño e inconveniente, porque los indios que vinieran de los pueblos se separarían de sus familias, tendrían que dejar sus milpas y haciendas por labrar, y los españoles se verían obligados a enseñar a cada nuevo indio que viniese cómo almohazar el caballo, ordeñar la oveja, hacer el queso y otras cosas de esta calidad, y en aprenderlo se acabaría el tiempo que el indio había de servir. En cuanto a la última categoría de indios, es decir, los que servían a los oficiales españoles, fray Francisco dijo al licenciado Cerrato que mandase examinar lo que habían servido al amo después que aprendieron los oficios, porque no era razón que, después de enseñarles durante tres o cuatro años el oficio, se les quitasen a los amos luego sin otra satisfacción ni servicio, pues aun los españoles mientras eran aprendices daban al maestro un tanto y cuando aprendían el oficio trabajaban algún tiempo en beneficio del que les había enseñado. Pero a pesar de los consejos del comisario fran. 
ciscano, el presidente Cerrato no hizo distinciones y libertó a todos los indios sin condición ni examen, con gran brevedad, dando un pregón tras otro.

Bustamante comparaba esta forma radical con la cauta empleada en México, donde todos los esclavos habían alcanzado libertad al pedirla y sin dilación se recibía el pleito a prueba y entretanto no consentía el virrey que los indios se entregasen con prisiones a los amos, sino que mandaba depositarlos en otra parte, para que los demás indios no dejasen de pedir su libertad, y cada semana el procurador puesto para los esclavos era obligado a hacer demostración de ellos el día que se lo mandaban y decir el estado en que estaba el negocio de cada uno. Creía que esto hubiera convenido hacer en Guatemala y luego apretar, y "porque lo de acá se hizo con golpe de martillo que suele atronar al que le da y aun al que le oye, llegó el sonido hasta allá, y porque en México se hizo con lima sorda, como se había de hacer, no se ha oído ni sentido el bien que se ha hecho". Bustamante informaba asimismo sobre otros aspectos de la reforma que no nos corresponde estudiar aquí. ${ }^{41}$

Este documento revela que al margen de la liberación de los indios se presentaba un resultado imprevisto: los artesanos españoles trataron en un principio de excluir a los indios libres del aprendizaje de los oficios calificados; pero bajo la confianza de que siempre gozarían del dominio sobre los indios esclavos, enseñaron a éstos los secretos de las artes. Ahora estos naturales quedaban en libertad y con los conocimientos necesarios para desempeñar las artesanias, de suerte que por un procedimiento indirecto y eventual, la población india lograba acceso a la maestría de los of icios europeos.

El licenciado Cerrato envió jueces visitadores a fin de libertar a los indios de las provincias, como ocurrió en la de Chiapa, a donde fué Gonzalo Hỉdalgo de Montemayor, quien llegó a Ciudad Real en 1549. No obstante el disgusto de los españoles, los esclavos fueron quitados y los naborias, chichihuas (indias nodrizas) y todos los in-

41 Academia de la Historia. Madrid. Colección Muñoz, LXXXVI, f. 15-24v. 
dios que estaban en casas de españoles, campos, ingenios de azúcar y comercio, puestos en libertad. Los religiosos asentaron los dedicados a oficios mecánicos en la vecindad del convento de Santo Domingo, donde se conservaban cuando Remesal escribió su Historia. ${ }^{42}$

Las medidas de libertad comprendieron, al fin, a esclavos machos y hembras de caciques indios, pues los señores de Santiago de Atitlán se quejaron en 1571 a Felipe II de que, a causa de las disposiciones de Cerrato, quedaron sin servicio y perdieron sus haciendas y plantaciones de cacao, por no tener quien las guardara. 43

Por último, los propios indios que conservaban en anales la historia de sus pueblos se dieron cuenta de la reforma implantada por Cerrato, así como de la evolución que había conducido a ella. ${ }^{44}$

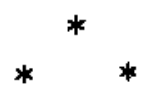

No pretendemos abarcar todas las quejas a que dió lugar la política antiesclavista de la Audiencia, pero es oportuno examinar algunos ejemplos que se conocen gracias a las investigaciones del profesor norteamericano L. B. Simpson.

El cabildo de Guatemala escribía a Cerrato, el 26 de septiembre

42 Simpson, Studies..., cit., p. 9.

43 Simpson, op. cit., p. 13.

44 Véase por ejemplo el libro de los Cakchiqueles o Memorial de Tecpán Atielán, Guatemala, 1934, números 152 y ss, cit. por J. Antonio Villacorta C., Historia de la Capitania General de Guatemala, Guatemala, 1942, p. 140: "Trescientos días después que Chii Xot fué tornada comenzó el pago del tributo al Capitán por Chinta Quej. Fué aquí en Tzololá, el dia 6 Tzii ( 14 enero 1528) cuando empezó el tributo".

"Durante este año (1530) se impusieron espantosos gravámenes: se pagaba oro y plata en la presencia de Tunatiuj, y se exigían como tributo quinientos hombres y quinientas mujeres para que fueran a buscar metal; toda la gente estaba empeñada en buscar oro. Quinientos hombres y quinientas mujeres también fueron pedidos por Tunatiuj, para ayudar en la construcción de Pangán. Todo esto nosotros lo presenciamos, 1 oh, hijos míos!"

"En el transcurso del año, el 11 noj (1536) Jlegó el Presidente Maldonado. El príncipe Maldonado llegó a aliviar a la gente de sus sufrimientos: el lavado de oro cesó pronto, y cesó también el tributo de hombres y mujeres; cesaron tambiën de quemar vivas a las personas, y los actos violentos, y los impuestos que nos hacían pagar los castellanos. Los caminos se vieron otra vez frecuentados, cuando llegó el príncipe Maldonado ;Oh hijos míos!"

"En el curso de este año (1549) llegó el Presidente Cerrato, mientras el Licenciado Pedro Ramírez permanecía aquí. Cuando llegó condenó a los castellanos; puso en libertad a los esclavos; disminuyó a la mitad los impuestos, puso fin al trabajo forzado y obligó a los castellanos a pagar por todo trabajo pequeño o grande". 
de 1548 , que no había sido bien informado en la materia de los escla. vos y que el bienestar de estas partes consistía en la permanencia de los españoles y en el poco oro y plata que se sacaba y no en el contento y opinión de los religiosos. El celo de éstos no contribuía a la conservación de la república. No se debían libertar los indios llamados esclavos, porque su número era ninguno comparado con el resto; al presente era mejor para ellos permanecer en compañía de los españoles que fuera de ella, porque los españoles los consideraban a los más como si fueran sus hijos. Si en tiempos pasados hubo descuido en su tratamiento, no era ya así, y ellos querían a los españoles por haberlos educado. Los esclavos trabajaban en las minas y gran parte del bienestar de los españoles dependía de este poco de oro. El Rey nunca había aclarado completamente la materia de la libertad de los esclavos. ${ }^{45}$

Bernal Díaz del Castillo, como procurador síndico de la ciudad de Guatemala, envía al Consejo de Indias, en 1 de febrero de 1549, una larga petición sobre los indios esclavos. Explica que el presidente y los oidores de la Audiencia "han mandado con ciertas penas que los que tienen esclavos indios los traigan ante ellos para darlos por libres a todos en general y mandaron se pregonase públicamente en la plaza pública de esta ciudad, como se pregonó, $y$ antes de esto han dado algunos por libres, lo cual es en agravio de toda la república e provincia". Suplica del mando y pregón, a más de las suplicaciones que antes hizo la ciudad. Expone luego las razones siguientes en defensa de su actitud: 1) los esclavos se hicieron en esta provincia por provisión real y conforme a la instrucción dada por el Rey, como consta de la matrícula que hicieron don Pedro de Alvarado, gobernador, y Jorge de Alvarado, su teniente en ausencia del gobernador, a quien vino cometido; 2) los esclavos de rescate se examinaron y constó claro ser esclavos en poder de los caciques y naturales que los tenían, y se les señaló con el hierro y entraron en el comercio de los españoles; 3) los caciques y señores que tenían a estos esclavos los vendían públi-

45 Ms. en Municipalidad de Guatemala, "Instrucciones y cartas". Vol. VI. Cit. por Simpson, op. cit., pp. 6-7. 
camente y atados en colleras y con unas varas los andaban vendiendo. y entre los indios se vendían en los tianguez (mercados) y el Rey permitió a los españoles que también los pudiesen comprar; 4) al comprar los indios los españoles fué en provecho de aquéllos, porque eran mejor tratados que entre los indios, que los sacrificaban a los idolos y les daban grandes trabajos y malos tratamientos; 5) los que se herraron en guerra fué con licencia del Príncipe, según derecho y conforme a instrucción real; fueron requeridos de paz y por su pertinacia y rebelión hechos esclavos; si hubo desafueros los han castigado las justicias reales; 6) desde que la Emperatriz mandó que no se hiciesen más esclavos (parece aludir a la cédula de 2 de agosto de 1530), cesó y no se hicieron más. En los que hasta ahí se habían hecho no se habló ni se dieron por mal hechos (se recordará que efectivamente la cédula citada prohibía la esclavitud en el futuro) ; 7) la ley nueva no manda que se den por libres todos generalmente, sino que el esclavo que pidiere libertad sea oído y con conocimiento de causa las Audiencias hagan justicia (interpretación distinta de la sostenida por Las Casas, pero compatible con las cédulas aclaratorias de 1545 y 1548) ; 8) de esta ley ha suplicado la ciudad y provincia y toda esta Nueva España y está admitida la suplicación y remitida a la consulta; 9) los oidores Ramírez y Rogel, con el presidente Maldonado, aconsejaron a los suplicantes que ocurriesen a la real persona, $\mathbf{e}$ informaron por su parte que no convenia al real servicio que todos los esclavos en general se diesen por libres; 10) el Rey respondió a otros capítulos, pero no al de los esclavos, por tenerlo remitido a consulta; 11) los esclavos se han vendido entre los españoles "por ser moneda e cosa de trato por el hierro de vuestra alteza que tienen e no se puede este negocio declararse por la gran confusión que habría en averiguación deste caso"; 12) el Rey ha llevado los quintos de todos los esclavos que se hicieron; 13) de concederse la libertad, cesarían los tratos de minas y demás granjerías y el Rey perdería los quintos, y la hacienda real vendría en gran disminución y los vasallos en pobreza; 14) los esclavos son bien tratados y relevados de traba. jos excesivos, en minas y demás granjerías, y son curados y tratados 
como a haciendas propias; 15) son industriados en la fe y tienen sacerdotes en minas y granjerías; 16) es negocio universal en Indias y hasta que el Rey lo mande universalmente, no puede la Audiencia de Guatemala hacer cosa en particular; las demás Audiencias no dan los esclavos por libres en general, sino con conocimiento de causa y orden de juicio, aguardando lo que por vuestra alteza les fuere mandado fuera de lo contenido en la dicha ley; 17) mediaron causas justas por que se hicieron esclavos los indios: pecados contra natura, comer carne humana, sacrificarse al demonio, impedir que se sembra. se la fe y predicase el Evangelio, rebelarse después de dar la paz, y otros crímenes y casos; son cosas que requieren, después de la disputa de letrados, la determinación real de lo que deba hacerse; la Audiencia no debe ejecutar cosa ninguna hasta que el Rey lo declare y medie consejo del Papa; 18) los esclavos en esta provincia y ciudad, así comprados de otras partes como los hechos en la provincia, no se tienen por esclavos para ser vendidos ni sacarlos de la provincia, sino para servirse de ellos moderadamente y no perder los señores los dineros que les costaron. El obispo de la ciudad don Francisco Marroquín mandó que los amos lo hiciesen así y no quería dar licencia para que fueran absueltos en sus confesiones hasta que todos lo prometieron y lo dieron firmado de sus nombres, y les señaló el trabajo que habían de tener con sus amos y señores; 19) esto es conforme a la provisión real para la isla de Santo Domingo que el presidente de la Audiencia de Guatemala quiere ejecutar en esta provincia, y así mandan el presidente y oidores que tales esclavos sean compelidos por las justicias ordinarias a que sirvan a sus amos, y de esta manera no hay para qué los naturales de esta tierra reciban alteración, como la reciben, y se amotinan los esclavos contra sus señores y se teme que hagan alguna cosa de que venga daño a todos los españoles; 20) dada la poca capacidad de los naturales para la fe y vivir como hombres y tener policía, convendría que los tuviesen a su cargo los españoles; andando libres y sueltos, los más viven como animales campestres en ásperas sierras y malezas de los montes; 21) si los esclavos se dan generalmente por libres, cesarán las siembras, ganados, edificios y de- 
más cosas necesarias; los españoles oficiales (es decir, artesanos) son pocos y los demás no tienen ese oficio; en el cuerpo de una república ha de haber hombres de todos estados, y estos indios son instrumento de la labor de la tierra y crianza y guarda de los ganados y de los oficios mecánicos; los españoles no lo son ni conviene a sus personas, como tampoco les conviene en Castilla, por no ser criados en ello ni en común ser oficiales; 22) si se quiere obrar con los naturales de estas partes, fuera de los esclavos no tienen industria de sembrar más que sus semillas, de las cuales no participan los españoles por no ser su manjar, ni tampoco saben hacer edificios más de sus jacales que hacen para sí, y no los edificios de una ciudad "ques necesaria para nuestra abitación e policia e fortaleza contra ella"; 23) si los escla. vos generalmente se diesen por libres, no obrarían cosa ninguna en el oficio en que están enseñados por los españoles, porque son holgazanes y odian a aquéllos; la experiencia muestra que los que saben oficios no obran sino con temor, y pensar remediarlo por fuerza, siendo ellos libres, es imposible, porque fácilmente se huyen y meten en los montes; 24) la cédula que alega haber el presidente de la Audiencia, en declaración de la ley nueva, fué dada para Santo Domingo y es particular voluntad de vuestra alteza para allí por las causas y razones que movieron a vuestra alteza, que no militan aquí, y porque los más esclavos que allí había son de estas partes (es decir, llevados del Continente a las islas), y no consta que sea la voluntad de vues. tra alteza que se ejecute en este distrito, porque si así fuera, también mandara vuestra alteza que se ejecutara aquí (ya sabemos, contra el razonamiento de Bernal, que el presidente Cerrato tenía autorización para aplicar la cédula de Santo Domingo en la Audiencia de los Confines); 25) después que se mandó lo contenido en la provisión pa. ra Santo Domingo, suplicó esta provincia y Nueva España de dicha ley para la persona real, y se admitió la suplicación, por donde consta no ser la voluntad de vuestra alteza que se ejecute dicha provisión de Santo Domingo en esta provincia; 26) obedecerá esta ciudad lo que el Rey mande con acuerdo del Consejo, con determinación del Santo Padre o en la manera que mejor parezca a vuestra alteza mandarlo 
así a esta ciudad como a todas las demás de estas partes, pues el negocio es universal. Termina pidiendo que se mande a la Audiencia sobreseer este negocio de dar por libres en general a todos los esclavos de esta ciudad y provincia de la manera que lo hacen y ejecutan, hasta que el Rey responda. La ciudad odebecerá. 46

En términos semejantes, aunque afortunadamente más breves, informan los vecinos de Guatemala al Rey, en 1 de agosto de 1549, que, por intervención de los frailes, Cerrato dió los esclavos por libres, siendo el mayor daño que se ha hecho en esta gobernación por la manera en que se dió la libertad. Hacía más de quince años que se habían dejado de hacer esclavos y ya no se harían más; a los esclavos que había los tenían sus amos por hijos: "tal servidumbre libertad era para sus ánimas e cuerpos"; los religiosos usan los indios para sí y censuran a los vecinos cuando se sirven de ellos. 47

Finalmente, el 22 de enero de 1554, se quejaba el cabildo de Guatemala, al Rey, de que Cerrato libertó los esclavos dentro de diez días después del registro y sin atender a las apelaciones. ${ }^{48}$

No obstante que los colonos defendieron con habilidad e insistencia sus puntos de vista, había triunfado esta vez en la Corte la corriente antiesclavista. Los recursos jurídicos no bastaron a detener la ejecución pronta a que se inclinó el enérgico Cerrato.

Es uno de los ejemplos más notables de reforma social iniciada en las alturas del pensamiento teológico y jurídico, llevada a la legislación real y finalmente aplicada en la colonia, a pesar de la oposición de los pobladores heridos en sus intereses.

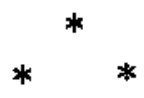

Generalmente los indios libres de Guatemala daban tributos y ser-

46 Publica el texto L. B. Simpson, op. cit., pp. 32-36, tomándolo del archivo par. ticular de don Ricardo Vázquez, de la ciudad de Guatemala. La numeración de los párrafos es nuestra.

47 Academia de la Historia. Madrid. Colección Muñoz, vol. 85, fols.113-116. Cit. por Simpson, op. cit., p. 8. He visto una copia en Public Library. New York. Spanish Mss. 65. Rich 3. Fol. 9v.

48 Ms. en Municipalidad de Guatemala, "Libro de consultas a S. M.", cit, por Simpson, op. cit., p. 11. 
vicios personales. Cuando los antiguos esclavos se equipararon a ellos por efecto de la emancipación, comenzaron a ser afectados por la legislación común relativa a los indios libres; pero en mérito a las penalidades que habian sufrido, obtuvieron algunas concesiones que en seguida estudiaremos.

Recién obtenida la libertad, los indios que habían sido esclavos en Guatemala comenzaron a ser repartidos a servicios de españoles en obras comunes y otros trabajos, en consideración a que no pagaban tributo. Ellos representaron al Rey que los servicios personales eran más penosos que el pago de la tributación y pidieron ser eximidos de dar aquéllos y que se les cobrase en cambio un tributo moderado, pero no por ahora, en atención a lo que habían padecido. El Rey, por cédula dada en Valladolid el 17 de junio de 1559, mandó que los indios libertados no fuesen compelidos a hacer las obras públicas ni privadas y fijó un plazo de tres años para que comenzaran a tributar como los demás indios libres. ${ }^{49}$ Cuando se cumplió el término, paga. ron los tributos; pero más tarde representaron, por medio de Alonso de Herrera, que no se cumplía la cédula de 1559 y que se les apremiaba a hacer las obras comunes y otros trabajos excesivos, como antes de que pagaran el tributo. La Corona, por nueva orden dada en Madrid el 25 de febrero de 1568, mandó guardar la cédula de 1559, amparando a los indios en sus preeminencias y libertades, y que no fuesen compelidos a las obras comunes, sino bien tratados como vasallos del Rey. ${ }^{50}$

De suerte que los indios emancipados debían legalmente tributar pasada la exención de tres años que fijó la cédula de 1559, y así lo hacían; pero subsistía a su favor, en 1568 , el privilegio legal de no concurrir a las obras públicas, de cuya violación protestaban con buena fortuna ante la Corte.

Hacia mediados de la década del 70 , los indios de las milpas que

49 Encinas, Provisiones..., IV, 379-380. En DIU., XXI, 254, se extracta así esta cédula de junio de 1559: a las autoridades de Guatemala que los indios que se pusiesen en libertad no fuesen compelidos a trabajar en los edificios públicos.

5o Encinas, loc. cit. AGI., Guatemala 394, libro 4, fol. $390 \mathrm{v}$, El sumario en $D I U$., XXI, 177, n. 48 . 
estaban en el distrito de la Audiencia de Guatemala expusieron que, no obstante las cédulas anteriores, eran agraviados porque pagaban más tributo del que podían dar: se cobraba a los mozos que estaban en servicio de sus padres, a los viejos y viejas que no lo podían ganar, a los viudos y viudas, y se exigía también el de los muertos. Servían, además, en obras públicas y privadas, barriendo calles y plazas, aderezando caminos, haciendo tablados y enramadas para las fiestas y otras cosas sin ninguna paga; se les pedían servicios especiales, asimismo, como dar amas para criar los hijos de los españoles, molenderos y gente para labrar tierras sin otra paga que tres reales por el trabajo de una semana. Si los alcaldes indios no daban el servicio, eran encarcelados. Los alcaldes y escribanos que se ocupaban en recoger y repartir a los indios de servicio, por cuya razón no podían acudir a sus granjerías, eran compelidos también a pagar el tributo como los que lo andaban trabajando. Como estos indios de las milpas no fueron mencionados en las dos cédulas anteriores, se les daba a entender que no rezaban con ellos, y la justicia no los desagraviaba; pedían que esto se corrigiera. El Rey mandó en el Pardo, el 24 de octubre de 1576, que la Audiencia cumpliera las cédulas, así con los indios que fueron esclavos como con los de las milpas y otros cualesquiera, y que los amparara. ${ }^{51}$

Esto revela que en 1576 seguía vigente legalmente la exención del servicio personal concedida por las cédulas de 1559 y 1568 a los esclavos libertados. Los indios de las milpas, o sea, el segundo de los cuatro grupos que distinguió el comisario franciscano de Guatemala, no habían gozado por lo visto de ese beneficio, a causa de no haber sido mencionados de manera expresa en los documentos reales; pero ahora se ampliaba a ellos el privilegio.

Como los esclavos libertados pagaban tributo desde que se venció la exención concedida en 1559, y queda aclarado que lo propio ocurría con los indios de las milpas desde fecha que no se precisa, pero desde luego anterior a 1576 , la única diferencia que subsistía entre

51 Encinas, loc, cit. 
el estatuto de los indios libertados y el de los indios libres que no ha. bían sido esclavos era con respecto a la obligación del servicio personal, que no debía alcanzar a los primeros y sí a los segundos.

Hallo otra derivación curiosa del estado jurídico a que quedaron reducidos los esclavos que habían sido puestos en libertad en este distrito. Cuando la Audiencia de los Confines recibió la cédula a que nos hemos referido de 17 de junio de 1559, mandó contar los indios que solían ser esclavos, para que pasados los tres años que en ella se concedían comenzaran a tributar al Rey. Alonso de Paz y otros comisionados hicieron la cuenta y metieron en ella a indios poblados que no pertenecían a la clase de los esclavos emancipados, sino que eran conquistadores que habían venido con los españoles, según representaron a la Audiencia, en enero de 1564, por medio del procurador Juan de Salazar, don Francisco de Oñate, don Antonio Ceynos, don Joan de Tapia, y Diego y Pedro Hernández, indios mexicanos y tlaxcaltecas, en nombre de ellos y de los demás indios de las dichas provincias y de los zapotecas y goatemaltecas principales y conquistadores de la provincia de Guatemala. Argumentaron que la cédula no se entendía con ellos, sino con los indios esclavos y advenedizos que estaban poblados en diferentes milpas. Hicieron hincapié en su condición libre y en que se hallaron en la conquista con el Ade. lantado don Pedro de Alvarado y otros capitanes. La Emperatriz - decían- les hizo merced, por una cédula real, de que no fuesen encomendados ni compelidos a prestar servicio alguno. Si después de la conquista permanecieron en Guatemala, fué a causa de la pobreza en que se encontraron. Pedían, en conclusión, que la Audiencia declarara que ellos y sus hijos y descendientes no debían pagar tributos perpetuamente.

La Audiencia de los Confines resolvió que, mientras se veía la causa, los indios que fuesen conquistadores no pagasen tributos y los demás sí. El gobernador Francisco Brizeño, por sentencia de 16 de noviembre de 1564, remitió el pleito al Consejo de Indias para que éste determinara lo que debía hacerse, pero mandó que los indios, entretanto, pagaran el tributo o dieran fianzas. Los indios ocurrieron 
a la Audiencia de México y ésta aprobó la remisión del caso al Consejo de Indias, según la había decretado Brizeño, pero dispuso que, entretanto, no se hiciera novedad en cuanto a la exención temporal de que disfrutaban los quejosos. A petición de éstos se despachó una carta ejecutoria en tal sentido en la ciudad de México el 30 de agosto de 1566. Habiendo sido presentada ante la Audiencia de la ciudad de Santiago de Guatemala el 2 de diciembre de 1570, ésta mandó que se cumpliera y que los indios conquistadores y sus descendientes no pagaran los tributos mientras se consultaba el caso al Rey. Este acuer. do coincidía con otro a que habían llegado, en cumplimiento de la carta ejecutoria de México, el licenciado Brizeño y el licenciado Valdés de Cárcamo, oidor, al tiempo que se hizo la cuenta y tasación del asiento de Almolonga, llamado Çaqualpa, por la cual declararon cuáles eran los indios conquistadores comprendidos en la exención.

El licenciado Arteaga Mendiola, fiscal de Guatemala, protestó de que se extendiera el privilegio a los hijos y descendientes de los indios, cuando la carta de México sólo hablaba de los que habían sido conquistadores.

En este estado se encontraba el pleito cuando se sacó el 28 de febrero de 1571 una relación para enviarla al Consejo de Indias. ${ }^{52}$

El expediente se refiere primordialmente -como es notorio- a la exención de tributos que obtienen algunos indios por los servicios que prestaron en la conquista de Guatemala; pero la actuación judicial se inicia porque se pretendía confundirlos con los esclavps libertados, cuya matrícula de tributos comenzó a ser preparada a consecuencia de la cédula de 1559. Esta es la razón por la que mencionamos el documento en el presente estudio.

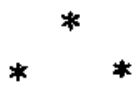

Las leyes de libertad cumplimentadas a mediados del siglo XVI

52 AGI., Patronato 231, n. 4, ramo 14. Copia fotográfica del Sr. F. V. Scholes, de la Institución Carnegie, depositada en la Biblioteca del Congreso. Wáshington, D. C. 
no forman el último capítulo en la historia de la esclavitud de los indios. Desde entonces quedó consagrado en términos generales el principio de la libertad del indio, pero la legislación indiana admitió algunas excepciones con respecto a naturales que se distinguían por su hostilidad a la dominación española. ${ }^{53}$

Veamos los casos que guardan relación con la Audiencia de Guatemala.

El Rey tuvo noticia de los daños que ocasionaban los indios de Lacandón a otros que estaban de paz, y encargó a los religiosos de Santo Domingo, que estaban en la Vera Paz, por cédula de 20 de enero de 1553, que intentaran la pacificación "guardando en ello la forma que les estaba dada para los de Vera Paz". ${ }^{54}$ También ordenó a la Audiencia de los Confines, en la misma fecha, que favoreciese esta empresa. ${ }^{55}$

El Obispo de Chiapa representó, poco tiempo después, lo alterado que se hallaba su obispado a causa de las incursiones de los indios de Puchutla y Lacandón, que eran muy perjudiciales e infestos a la fe, destruían los pueblos y mataban mucha gente. El Rey envió a la Audiencia de los Confines esta carta el 22 de enero de 1556 y le ordenó que se informase de los hechos y castigase y remediase los perjuicios conforme a lo que pudiese y debiese hacer en justicia. ${ }^{56}$

Agotados estos recursos, careciendo el Rey de noticias sobre lo que se había ejecutado, y habiendo recibido nuevos informes de los dominicos acerca de la continuación de los ataques de los indios, dirigió a la Audiencia de los Confines otra cédula el 16 de marzo de 1558, por la que acordaba el envío de gente para llevar a los indios de Lacandón y Puchutla a poblar a otra parte de los términos de Chiapa, señalando a quienes se ocupasen en ello, de los tributos que se impu*

53 La Recopilación de Indias, ley 1, título 2, libro VI, ordena que ninguna persona "sea osado de cautivar indios... ni tenerlos por esclavos... excepto en los casos y naciones que por las leyes de este título estuviere permitido". Se trata en el código de 1680 de los caribes (ley 13, tit. 2 , libro VI), los araucanos (leyes 14 y 16, tít. 2, hibro VI) y los habitantes de Mindanao (ley 12, tít. 2, libro VI).

st Archivo Histórico Nacional. Madrid. Cedulario Indico, t. VI, fol. 263, n. 434.

ss Loc. cit.

s6 Ibid., t. VI, fol. 264, n. 437. En 1555 era obispo de Chiapa fray Thomas Casillas. Cfr. F. Sosa, El Episcopado Mexicano, México, 1877, p. 19. 
siesen a los indios, la parte que pareciese proporcionada al riesgo a que exponían sus vidas y al trabajo que tuviesen; si por este medio no se aquietasen los indios, se les podría hacer la guerra, no obstante la prohibición de la ley, y dar por esclavos a los que se cautivasen, con el menor daño que fuese posible. ${ }^{57}$

De suerte que la Corona había comenzado por apoyar la intervención pacífica de los religiosos, pero en vista de la persistencia de los ataques de los indios, concluía por autorizar en última instancia la guerra y la esclavitud. Esta autorización no deja de causar cierta extrañeza, ya que era tan reciente la libertad concedida a los esclavos de guerras anteriores. No tocó al licenciado Cerrato ejecutar la nueva orden, porque en enero de 1555 había sido sustituído por el doctor Antonio Rodríguez de Quesada, quien falleció en noviembre de 1558, sucediéndole en el gobierno el oidor licenciado Ramírez de Quiñones, al cual correspondió organizar la expedición contra los la. candones, habiendo regresado a Guatemala en 1559. El 2 de septiembre de este año tomó posesión del gobierno el licenciado Juan Núñez Landecho.

Todavía se encuentra otro caso más tardio de excepción a las leyes dictadas a favor de la libertad de los naturales. Por cédula fechada en Badajoz el 26 de mayo de 1580, el Rey refiere al presidente y oidores de la Audiencia de Guatemala ser informado que los indios chontales son caribes y comen carne humana, y demás de vivir en ceguedad de su idolatría, cometen muchos delitos, matando y robando a sus comarcanos que están de paz y a algunos españoles, y por estar en tierra áspera no se pueden castigar, y que se entiende que dándolos por esclavos habría quien entrase por la tierra y se irían sacando de ella y vivirían entre cristianos. Visto en el Consejo de Indias, ha parecido que se podría poner medio en esto y podría ser condenarlos a servicio por algún tiempo; pero a causa de haberse entendido estos daños tan sólo por relaciones de personas deseosas del servicio real que lo han escrito, no se ha tomado resolución más de en remitirlo a

57 Ibid., t. VI., fol. 265, n. 438. AGG., A. 1. 23, 1511. 236. 
la Audiencia, y así se le manda que, si habiéndose informado de todo muy particularmente le pareciere que conviene dar dichos indios a servicio por algún tiempo, de manera que no sea por esclavos, lo pondrá en ejecución por la mejor orden que le pareciere y dé aviso. 58

En este ejemplo no se autoriza una esclavitud perpetua, sino un servicio temporal, pero a juzgar por las prácticas adoptadas en Nueva España y Guatemala, podía extenderse a períodos de diez años y más. Se habrá observado que el Rey no toma una resolución definitiva acerca de este castigo, que remite a la Audiencia.

En relación con las cédulas de excepción citadas, conviene tener en cuenta un informe que eleva Antonio de León Pinelo al Consejo de Indias en 1639. Relata que hacia 1550, los lacandones que siempre habían permanecido en su gentilidad incursionaron causando daños en Tuzutlán o Verapaz, provincia ganada por la predicación pacífica de los dominicos desde 1537, y en otras poblaciones vecinas de cristianos. En 22 de febrero (sic) de 1556 se despachó real cédula a la Audiencia de los Confines para que castigase los crímenes de los rebeldes. Es de advertir que las incursiones de los lacandones habían provocado el alzamiento de indios ya reducidos. A causa de estos estragos, cuando se reunió en 1558 el capítulo de los dominicos en Cobán, se discutió si sería justo hacer guerra y conçuistar por fuerza de armas a los indios lacandones y puchutlas, no por ser infieles o por comer carne humana, lo cual hacian, sino por haber quemado muchas iglesias, destruído imágenes, sacrificado niños de los cristianos a sus idolos en los altares y al pie de las cruces, y cometido otras injurias, insultos y crímenes. Se resolvió que no sólo podria hacérseles guerra, sino que el Rey debía defender a sus súbditos cristianos y destruir a lacandones y puchutlas por sus crueldades. Los daños continuaron, y el Consejo de Indias mandó a la Audiencia, en 16 de marzo de 1558, haciendo referencia a la cédula de 1556, que los lacandones que causaban los daños fuesen sacados de sus tierras y trasladados a regiones despobladas en otras partes de Chiapa, y para animar a los vecinos de Chiapa y Guatemala, se les recompensaria 58 AGG., A. 1. 23. 1513. 573. 
con los tributos de los lacandones trasladados; si por este medio no podian ser reducidos, tomada suficiente información, se les haría guerra y los prisioneros serian esclavos.

Hasta aquí la narración de León Pinelo confirma y aun amplía lo que expusimos a base de la lectura de las cédulas reales.

Añade que la provisión de 1558 se publicó en Guatemala, Chiapa y provincias vecinas, y que se organizó una expedición contra lacandones, puchutlas y acalaes bajo el mando de Pedro Ramírez de Quiñones. Iban españoles y más de 2,000 indios amigos. Dos bergantines se destinaron a servir en la laguna de Lacandón. Se hicieron cerca de 150 prisioneros en la isla; otros se tomaron a los puchutlas. Los indios de Verapaz atacaron a los acalaes y tomaron 240, de los cuales ahorcaron a 80 . Los cautivos escapaban y volvían a sus tierras. Con el castigo se aquietaron los indios hostiles por algunos años, pero luego reanudaron sus ataques. León Pinelo atribuía a esto el que se suprimiese en 1609 el obispado de Verapaz, fundado en 1559, para ser unido al de Guatemala.

Los indios de Puchutla fueron por fin convertidos y los frailes los pusieron en Ocotzingo, donde habían permanecido, aunque algunos quedaron en el lugar de origen. Hacia 1606 ya se habían convertido también algunos pueblos de Manché por obra de los frailes. Y se hacían esfuerzos para comunicar Verapaz con la laguna de Términos o Xicalango y para convertir a los habitantes de esa zona. En 1625, en nombre del Rey, se tomó posesión de dieciocho pueblos de la región de Manché. Pero en 1628 los lacandones atacaron hasta llegar a seis leguas de Cobán; tomaron indios cristianos, algunos de los cuales sacrificaron en seguida. Los taizaes, en 1630, atacaron por el otro lado de Manché e hicieron más de 300 prisioneros entre los nativos, mataron a los jefes y se llevaron a los demás; se comieron a don Martín Cuc, gobernador de la provincia; llevaron consigo a las mujeres y a los niños bautizados; mataron a un fraile, etc. Once pueblos se rebelaron a consecuencia del ataque y rechazaron la obediencia y la fe que habían recibido.

El justicia mayor de Verapaz, Martín Alonso Tuvilla, y el pre- 
sidente de la Audiencia, por decreto de 11 de marzo de 1631, resolvieron fundar en Manché una ciudad de españoles y mestizos. Desde 1632 se cobrarían tributos a los indios manché por haber cumplido los diez años de exención que se concedían a los neófitos. También se mandó que los indios lacandón, yole y agitzaes que los españoles capturasen en guerras, fuesen tomados por esclavos para hacer uso de ellos por diez años, hasta que su majestad mandase otra cosa. Así se ponía en ejecución la cédula real de 1558 , con dicha limitación en cuanto al tiempo del servicio. Se fundó entonces la ciudad de Toro de Acuña en San Miguel del Manché. Las hostilidades entre españoles e indios continuaron hasta que la ciudad fué incendiada y los españoles e indios cristianos se retiraron a Verapaz y dejaron Manché sin defensa. Tal era la situación en 1635.

Varias personas habian solicitado emprender la pacificación de la zona y para dar luz sobre este proyecto Antonio de León escribió su informe. ${ }^{59}$

En resumen: la hostilidad en algunas regiones de Indias daba lugar a que se alterase la regla general a favor de la libertad de los naturales, autorizándose en último término, más bien que la esclavitud perpetua de los cautivos de guerra, el servicio de los mismos por un número dado de años.

59 Cfr. D. Z. Stone, "Some Spanish Entradas, 1524-1695", Mid. Am. Res. Ser, No. 4, pp. 209-296. Tulane University, New Orleans, 1932. El informe de León en pp. 237.255. 



\section{LAS ENCOMIENDAS}

No he reunido datos suficientes para trazar el proceso de la encomienda en Guatemala, pero los que analizaré en seguida permiten fijar algunos aspectos característicos de ella en esta región.

El primer documento nos ilustra sobre una modalidad de orden judicial. Ocurrió que Francisco Girón, vecino y regidor de la ciudad de Santiago, en nombre de ella y de la provincia de Guatemala, hizo relación a la Corte que después que el licenciado Cerrato presidía en esa Audiencia, en todos los pleitos que ante él se habían tratado sobre indios, luego que se daba sentencia en vista contra alguno privándole de tales indios, la ejecutaba, sin embargo de que la parte condenada suplicara de ella, y sin esperar el grado de la suplicación y en perjuicio de ella, y le despojaba y quitaba la posesión, habiendo grado, de que se recibía agravio, y de esta manera estaban despojados muchos de sus indios, contra justicia, y que en revista nunca se sentenciaban los tales pleitos. Pedía remedio y que se mandara que en perjuicio de dicha suplicación, habiendo lugar y suplicándose en tiempo y en forma de la sentencia de vista, no la ejecutasen hasta que se confirmase aquélla en revista y se diese carta ejecutoria. Visto en el Consejo de Indias, fué acordado dar la presente cédula que el Príncipe dirige al presidente y oidores de la Audiencia de los Confines, desde Madrid, a 17 de abril de 1553, mandándoles que vean lo susodicho y hagan justicia conforme a las leyes y provisiones que sobre ello están dadas. ${ }^{60}$

60 AGG., A. 1-2-4. 2195. 24v, 
Esto confirma que Cerrato, en su afán de ejecutar las reformas que se le habían encomendado, prescindía de las trabas procesales; pero los pobladores invocaron las garantías tradicionales del Derecho, con el resultado de que la Corte mandó que se cumplieran las leyes y provisiones dadas, que en la época de que tratamos eran las ordenanzas de Barcelona, pero ya reformadas en algunos capítulos tocantes a las encomiendas. 61

Una muestra del rigor con que la Audiencia presidida por el licenciado Cerrato castigaba a los encomenderos que se excedían en el cobro de la tasa de los tributos, nos ofrece el pleito que siguió el fiscal de la propia Audiencia contra Andrés de Rodas.

En la ciudad de Santiago de Guatemala, a 23 de enero de 1554, se abrió proceso en la Audiencia contra dicha persona, que tenía en encomienda el pueblo de Oçuma, "por llevar más tributos de los que por la tasa le habían de dar los indios y servídose dellos". Se tomaron declaraciones al cacique y a los principales. El pueblo daba de tributo cada año cuarenta tostones de a cuatro reales de plata y veinticuatro gallinas de Castilla y todos los viernes de cuaresma unos treinta pescados y todos los viernes del año doce huevos y solían sembrar una hanega de maíz y de ella cogían sesenta hanegas, las cuales le traían al encomendero a esta ciudad los indios del pueblo a cuestas, y solamente un año les pagó la traída, que dió a cada indio sesenta cacaos. Este año sembraron tres hanegas, porque lo mandó el licenciado Ramírez pasando por el pueblo.

El fiscal pedia que se castigara al encomendero conforme a justicia por haberse excedido en el cobro de la tasa.

La parte del encomendero alegó que no había cargado indios en caso prohibido, y si algunas veces los había cargado, fué con el maíz de la tasación y con licencia del licenciado Pedro Ramírez de Quiñones, oidor, y que pagó a cada indio el precio contenido en la licencia, y las cargas fueron moderadas y las que ellos quisieron traer de su voluntad.

61 Véase a este respecto mi obra La Encomienda Indiana, Madrid, 1935, pp. 110 y ss. 
Como prueba se exhibió la licencia de Ramirez, fechada en Guatemala a 30 de mayo de 1550 , que autorizaba al encomendero a que con los indios de su encomienda pudiera traer a dicha ciudad los tri. butos del pueblo de Oçuma, pagando a cada indio medio real de plata por cada día o su valor en cacao.

También se encuentra entre las pruebas una tasación hecha por el presidente y oidores en la ciudad de Santiago de Guatemala, a 4 de mayo de 1549 , por la que fijaron los tributos del pueblo de $0_{\text {çuma, }}$ encomendado en Andrés de Rodas, al año, en una sementera de maíz de una hanega, que cogerían y encerrarían en dicho pueblo, y darían dos docenas de gallinas de Castilla y cada viernes una docena de huevos y en cuaresma cada semana un arrelde de pescado; asimismo tres indios ordinarios de servicio en dicha ciudad, con obligación de darles de comer todo el tiempo que le sirvieran y de enseñarles la doctrina. No se les llevaría otra cosa. El 1 de octubre de 1549, el licenciado Cerrato mandó que, en lugar de los tres indios de servicio, dieran cada año cuarenta tostones de a cuatro reales cada uno, la mitad por San Juan y la otra por Navidad, y recalcaba que no habían de dar dichos indios de servicio. Esta variación obedece sin duda a la cédula real de 22 de febrero de 1549, que prohibió la inclusión de los servicios personales en la tributación de las encomiendas. ${ }^{62}$ Buen número de conmutaciones del servicio en pagos de distinto género pueden verse en otras tasaciones de la jurisdicción de Guatemala. ${ }^{63}$

El 27 de abril de 1554, los licenciados Cerrato, Ramírez y Tomás López fallaron contra el encomendero Andrés de Rodas condenándolo a privación perpetua del pueblo e indios de $\mathrm{O}_{\text {çuma, }}$ los que en calidad de vacos se podrían encomendar en otra persona. El sentenciado pagaría también las costas del pleito.

La parte del encomendero pidió la revocación y el fiscal la confirmación de la sentencia.

En 25 de septiembre de 1554, los licenciados Cerrato, Ramírez, Corita y López fallaron que revocaban la sentencia y condenaron a

62 Puga, Provisiones..., II, 14-18.

63 Cfr. Epistolario de Nueva España, cit., V, 207 y ss. 
Rodas a pagar siete pesos de oro para cosas necesarias a la iglesia de Oçuma, y las costas. Se dió el mandamiento ejecutivo, con el que concluye el expediente. ${ }^{64}$

No se mantuvo, en consecuencia, el rigor de la primera sentencia; pero con jueces resueltos a castigar los excesos, era probable que las tasaciones de los tributos fueran respetadas por los encomenderos en mérito a su conveniencia propia.

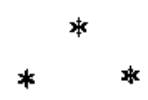

En los últimos tiempos ha sido objeto de investigación el tema de la propiedad territorial dentro de las encomiendas. Las tierras de éstas ¿pertenecian al Rey, al encomendero, a otros españoles, al pueblo de los indios en común o a éstos en particular? No vamos a repetir aquí las conclusiones generales a que han llegado los investigadores, pero sí nos proponemos examinar algunos documentos de la jurisdicción de Guatemala que contribuyen al esclarecimiento del problema. 65

En la ciudad de Toledo, el 8 de noviembre de 1538, el Emperador Carlos $\mathrm{V}$ mandó dar una cédula en la que decía que por parte del consejo de la villa de San Cristóbal de los Llanos de Chiapa le fué hecha relación que muchos vecinos de esa villa habían plantado, en los repartimientos que tenían encomendados, parrales, viñas y otros géneros de árboles, y otros tenían voluntad de plantar más en el futuro en dichos repartimientos, y suplicaban se mandase que lo que así bubieren plantado y plantaren en adelante en dichos repartimientos, fuese suyo y de sus herederos, y que aunque la encomienda les fuese removida, la persona que en dicho repartimiento tuviere heredades se que-

64 AGG., Paquete 375. Exped. 1.

65 Noticias más amplias sobre el mismo pueden verse en mi estudio De encomiendas y propiedad territorial en algunas regiones de la América española, México, 1940, y en el artículo de F. A. Kirkpatrick, "The Landless Encomienda", en The Hispanic American Historical Review, XXII, No. 4 (November, 1942), pp. 765.774. Ha sido traducido al español bajo el título "La encomienda sin tierras", en Revista Chilena de Historia y Geo. grafía, 102 (1943), 363-374. 
dase con ellas, y fuese obligado el que sucediese en el repartimiento a comprarlas, dando por ellas lo que dos personas puestas por ambas partes jurasen que valiesen.

El Emperador lo tuvo por bien y mandó que:

"no habiendo tomado ni tomando para hacer las dichas viñas y parrales y otras arboledas, tierras ni heredades de los indios naturales de esa tierra contra su voluntad y sin pagárselas, es nuestra merced y voluntad que todas las heredades que ansí los vecinos de esa dicha villa hubieren plantado en los repartimientos que les están encomendados y las que plantaren de aquí adelante, sean suyas y de sus herederos y sucesores de aquel o aquellos que de él o de ellos hubieren título, razón o causa, y mandamos que aunque la encomienda de los indios que ansí os están encomendados ${ }^{66}$ o sea removida la persona que en el dicho repartimiento tuviere heredades, se quede con ellas y sea obligado el que sucediere en el dicho repartimiento a las comprar, dando por ellas lo que dos personas puestas por ambas partes juraren y declararen que valen".

Y todavía en Madrid, a 23 de enero de 1566, el Rey escribe al presidente y oidores de la Audiencia de Guatemala que desea ser informado de lo que se ha hecho en esa provincia cerca de lo dispues. to por dicha cédula, y si se ha ejecutado, y si habrá algún inconveniente en guardarlo en adelante, por haber tanto tiempo que se dió y la diferencia que hay del de entonces al de ahora. La Audiencia enviará al Consejo de Indias relación particular de todo ello, juntamente con su parecer, para que visto se provea, y, en el entretanto, en los casos que se ofrecieren, hará justicia conforme a derecho y leyes de estos reinos. 67

Se percibe claramente la diferencia entre la propiedad firme y hereditaria de la tierra sembrada, y el derecho de encomienda sujeto a las contingencias de las remociones gubernativas. Como los encomenderos sabían que podían perder la merced de la encomienda, habían procurado garantizar, por medio de la cédula real de 1538 , sus derechos

66 Parece faltar algo.

67 AGG., A. 1-2.4. 2195. 219. DIU., XXII, 55, n. 175. 
a las siembras hechas. Pero sin duda para evitar litigios entre el dueño de la heredad sembrada y el encomendero que por nuevo título entraba en posesión de la encomienda, se mandaba que éste comprara obligatoriamente los sembrados de aquél por el justo precio arbitrado. No era, pues, el título de encomienda el que daba derecho al nuevo beneficiario a gozar de estas tierras sembradas, sino la compra hecha al antiguo encomendero o a sus herederos. $\mathrm{Y}$ nótese también que la cédula real ponía por condición que no se tratara de tierras usurpadas a los indios, sino obtenidas por medios legítimos.

No sólo por su significación para el tema de que ahora nos ocupamos, mas también por tratarse de bienes de la familia del famoso cronista de Nueva España, Bernal Díaz del Castillo, es digna de estudio la titulación de la finca La Concepción en San Juan Sacatepequez, que me permitió examinar su poseedor don Antonio Goubaud.

De la lectura se desprende que ante el licenciado García de Valberde, presidente de la Audiencia de Guatemala, pareció Francisco Díaz del Castillo y dijo que tenía necesidad, para ayudarse a sustentar, de hacer una labranza, y para ello había tierras en término del pueblo de San Juan Chaloma de la encomienda de Bernal Díaz del Castillo, su padre, las cuales tenían los linderos que se describen en el documento. El solicitante alegaba ser hijo de uno de los primeros descubridores y conquistadores de toda la Nueva España y pedía merced de cuatro caballerías de tierra. Bartolomé Canseco fué comisionado para ver las tierras y recibir información, citados los indios, cerca de si estaban en perjuicio de alguna persona. Dió por parecer que estaban sin perjuicio y que eran baldias y realengas. El presidente hizo la merced de las cuatro caballerías a favor del citado Díaz, para él y sus herederos; las poblaría dentro de un año y no podría venderlas dentro de cuatro años. La merced se concedió en la ciudad de Santiago de Guatemala a 21 de enero de 1579.

En este ejemplo no es el propio encomendero quien recibe una merced de tierras dentro de los términos del pueblo encomendado, sino un hijo suyo; pero es de pensar que Bernal Díaz aprobaba la concesión, a juzgar por otro documento que en seguida analizaremos. 
En efecto, por la misma época Bernal Díaz se opuso a que se dieran a Martín Ximénez ciertas tierras de Izcuintepec, en los términos del pueblo de Guanagazapa, también de la encomienda del citado conquistador. No desconocía la primacía del derecho de los indios sobre esas tierras, pero razonaba que en caso de que la Audiencia resolviera darlas por merced, habían de ser preferidos sus hijos. El 31 de agosto de 1580 la Audiencia amparó a los indios en esas tierras. ${ }^{68}$

En la titulación de la finca La Concepción se encuentra otro texto relativo a los derechos de encomenderos $\mathrm{e}$ indios a la propiedad de la tierra. En la ciudad de Santiago de Guatemala, a 3 de enero de 1589, ante don Carlos de Arellano, alcalde ordinario, en presencia del escribano Juan de Guebara y testigos, mediante Martín de la Cueba, intérprete, parecieron ciertos indios del pueblo de San Juan Chaloma y dijeron que vendían en nombre de ellos y los demás indios del pueblo, a Francisco Díaz del Castillo, su encomendero, un pedazo de tierra situada en términos de dicho pueblo, en que el referido Francisco Díaz tenía de presente sembrada una sementera de trigo de tributo. A continuación se explican los linderos. La cual tierra que así le venden podrá ser una caballería poco más o menos, y declaran que dicha tierra que así le venden es el pedazo de tierra en que de presente le hacen a Díaz la sementera de trigo de tributo. Es declaración que Díaz les ha de dar siempre tierra en que hagan dichos indios la sementera de tasación, y los indios se obligan a que, siendo menester, harán roza nueva para hacer su sementera de tasación en dicha tierra. El precio de venta es de 200 tostones de a cuatro reales de plata. La paga se hizo ante el alcalde y los testigos.

Las novedades del caso consisten en que ya Francisco Díaz es el encomendero y no su padre Bernal. Ahora, para convertirse en propietario de tierras situadas dentro de los términos de la encomienda, no se vale de una merced del gobierno, sino de una operación de com. pra a los propios indios encomendados. Es importante también que se

69 Cfr. L. B. Simpson, "Bernal Disz del Castillo, Encomendero", en The Hispanic American Historical Review, Vol. XVII, No. I (February, 1937) pp. 100-106. Y S. Zavala, De encomiendas. .., cit., pp. 27-28 y 48 . 
trate precisamente del pedazo de tierra que se venía destinando a la sementera del tributo; esto es, los indios la cultivaban para el encomendero a cuenta de su obligación de darle especies agrícolas. De suerte que, desde tiempos anteriores a la venta, el encomendero gozaba de los frutos de esa sementera; pero ahora obtenía la propiedad de la tierra misma, que hasta entonces era de los indios encomendados.

Este documento de 1589, unido al de 1579 que antes hemos mencionado, comprueba la sostenida tendencia de la familia del enco. mendero a convertirse - por titulación específica y distinta de la propia de la encomienda, o sea, por merced y compra- en propietaria de tierras comprendidas dentro de los términos de los pueblos encomendados. Así iba naciendo una hacienda so capa de la encomienda, pero con independencia en cuanto a la titulación jurídica.

Más aún: ante el presidente Pedro Mallén de Rueda, el propio Francisco Díaz del Castillo pidió, en términos del pueblo de San Juan Sacatepequez, unas lomas montuosas, tierras baldías y realengas, sin perjuicio de tercero. Se hizo la vista de ojos, citados los indios, y se concedió la merced de dos caballerías de tierra para el solicitante y sus herederos; las poblaría en un año y no podría venderlas dentro de cuatro. Esta nueva merced se otorgó en la ciudad de Santiago de Guatemala a 8 de noviembre de 1590.

Las tierras obtenidas por Francisco Díaz fueron objeto de composición con el Rey en 1596. Al darse el título en Santiago de Guatemala, a 15 de diciembre de 1638, don Alvaro de Quiñones Osorio, presidente de la Audiencia, dijo que hacía la merced: "con calidad de que siempre que parezca es en perjuicio de los indios, sea en sí ninguna la dicha composición, por los inconvenientes grandes que resultan de lo contrario y que a los dichos indios cuando se hacen las diligencias y como incapaces no entienden para que son citados, vicio ordinario suyo, son engañados".

Este criterio protector, a juzgar por lo que enseña el mismo legajo que venimos estudiando, no prevaleció siempre, pues más tarde los indios se opusieron a concesiones de tierras a favor de los españoles y no fueron amparados. La realidad es que la hacienda llegó a consti- 
tuírse en aquellos términos, representando la irrupción - legal o abusiva- del propietario europeo y sus descendientes en medio de las posesiones de los pueblos de indios. La encomienda no influía directamente en este proceso, pero ya se ha visto que el encomendero que no se ceñía a su función específica, podia por otros medios convertirse en propietario de tierras y crear una hacienda dentro de la encomienda. Lo que no sabemos aún es con qué frecuencia ocurrió este fenómeno, pero es posible averiguarlo en regiones circunscritas de Indias, a base de un cotejo escrupuloso de los títulos de encomienda con los que amparan la propiedad territorial en la misma zona, inquiriendo asimismo el parentesco entre las familias de los encomenderos y las de los hacendados. $68 \mathrm{a}$

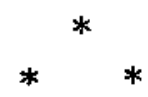

Los documentos que se conservan en Guatemala aclaran otros aspectos de la encomienda relacionados con la ausencia del beneficiario y su falta de derecho, en tal caso, para disponer de los tributos de los indios. En efecto, el licenciado Eugenio de Salazar, fiscal, representó que Juan Porcel, vecino que era de la ciudad de Granada en la provincia de Nicaragua, sucedió por muerte de su padre en la encomienda de los indios del pueblo de Xenti, provincia de Managua, el cual, queriéndose ir al Perú, dejó dichos indios a Diego de Pastrana, vecino de la misma ciudad de Granada, y se fué sin licencia de la Audiencia. Hacía más de cinco años que Porcel se había ausentado, y Pastrana había detentado los indios y tributos sin título, usurpando a la real caja, por pertenecer a la Corona dichos indios que quedaron vacos por la ausencia de Porcel. El fiscal pedía que los Oficiales Rea. les de aquel partido cobrasen y metiesen en la real caja los tributos

68. No se crea, sin embargo, que la Corona dejó en absoluta likertad a los encomen. deros para adueñarse de las tierras de las encomiendas. Sobre este tema conviene tener presente mi citado estudio De encomiendas y propiedad territorial, p. 24 y ss., y en particular la cédula que dió Felipe IV en Madrid, a 31 de marzo de I631, para que ningún encomendero pudiera tener, por sí ni persona interpuesta, estancias dentro de los términos del pueblo de su encomienda, y si las tuviere, se le quitaran y vendieran. Recopilación de Indias, ley 17 , titulo 9 , libro 6 . 
que procedieran de dichos indios como vacos y que cobrasen a Pastrana todos los tributos corridos que había recibido después de la ausencia de Porcel.

Esta petición se dió en Santiago de Guatemala, a 21 de junio de 1577, y la Audiencia mandó que se diera información.

La parte de Pastrana alegó que, deseando Porcel pasar a estudiar a la ciudad de Guatemala, pidió prestados 200 pesos a Juan Xaramillo, vecino de Granada, el cual se los dió sobre la encomienda de los indios del pueblo de Xenti, teniendo dichos indios en empeño hasta tanto que cobrase de ellos los 200 pesos. Para este efecto, Porcel hizo un traspaso ante la justicia y escribano a favor de Xaramillo, y éste con poder y más recados fué cobrando de la encomienda de esos indios 63 pesos. Queriendo Xaramillo ir con el gobernador Aguaçiana a la provincia de Costa Rica a servir a su majestad, cedió y traspasó en Pastrana los derechos y acciones que tenía del dicho Porcel para cobrar de los indios 137 pesos que restaban, los cuales Pastrana cobraba con título y buena fe, por otros tantos que había dado a Xaramillo por hacerle buena obra. Pastrana cobró la suma referida en año y medio, y luego que fué pagado, recurrió a la justicia y dió noticia de como los indios estaban vacos por ausencia de Porcel, aunque no habían pasado los dos años que dice la cédula real (relativa a las encomien. das de los ausentes), y la justicia nombró depositario al mismo Pastrana pidiéndole fiador. Terminaba esta parte solicitando ser absuelta de lo pedido por el fiscal.

La Audiencia falló en la ciudad de Santiago de Guatemala, a 10 de noviembre de 1579, que el fiscal probó su acción; en consecuencia, dió por vacos los indios del pueblo de Xenti y condenó a Pastrana a que volviera y metiera en la real caja lo que confesaba haber co. brado de tributos, dejándole a salvo su derecho contra quien le convi. niera. Se mandó dar la ejecutoria, con la que concluye el expediente. ${ }^{69}$

De suerte que si bien se habían efectuado los traspasos de la renta de la encomienda, fueron desautorizados apenas llegó la noticia a los

69 AGG., Paquete 344. Exp. 1.

62 
tribunales superiores, declarándose de manera terminante que, a partir del momento de la ausencia del encomendero, los indios pasaron en calidad de vacos a la Corona, no pudiendo su renta servir para pagar a los acreedores del ausente, que, en este ejemplo, había trocado la encomienda por el estudio.

El siguiente documento nos revela algunos pormenores sobre la edificación de una iglesia en un pueblo de encomienda. Luis Deardon representa a la Audiencia de Guatemala, en 30 de junio de 1586, que es encomendero del pueblo de Comalapa y desde hace dos o tres años se le ha llevado la cuarta de sus tributos por mandado de la propia Audiencia. La capilla de dicho pueblo, aclara, está cubierta y la iglesia se va haciendo de tal suerte que no se acabará en estos seis años y no se sabe en qué se gasta lo que se le ha llevado, que sube de 3,000 tostones. Pide que no le cobren la cuarta hasta que sea necesario y que se tome la cuenta.

El guardián del pueblo, fray Antonio Tineo, contesta que de la cuarta se han juntado hasta 1,900 tostones; explica los gastos hechos en la obra; y concluye que es necesario proseguir la cobranza de la cuarta.

Se celebra finalmente un concierto entre el encomendero y los indios, con fecha 11 de noviembre de 1588, por el que se compromete el primero a dar 1,500 tostones, a más de lo que había dado de la cuarta, para que se acabe la fábrica, sin que se le pueda pedir más. La Audiencia aprueba este arreglo. ${ }^{70}$

Debe tenerse en cuenta que por una provisión dada en Monzón el 2 de agosto de 1533, la Corona dispuso con carácter general que para hacer las iglesias se apartara hasta la cuarta parte de los tributos que correspondieran al Rey, al Marqués del Valle y a los encomenderos en sus respectivos pueblos. ${ }^{71} \mathrm{Al}$ parecer esta regla se había extendido a Guatemala y estaba vigente más de cincuenta años después de su establecimiento.

En cuanto a la sucesión de las encomiendas, encontramos que

70 AGG., Paquete 319. Exp. 4.

1) DIU., X, 171. Puga, Provisiones. ., I, 309-312. 
el licenciado Pedro Mallén de Rueda, presidente de la Audiencia, da una orden en Santiago de Guatemala, a 12 de septiembre de 1590, en la que dice haber sido informado que en las provincias de Nicaragua y San Salvador han muerto algunos encomenderos de primera encomienda sin tener sucesores, y las mujeres quedan con los indios, las cuales por segunda vez se casan, $y$, muriendo, se quedan con las encomiendas los maridos de segundas nupcias; y asimismo sucede que habiendo muerto algunos encomenderos que gozaban las encomiendas en segunda vida, las mujeres o hijos entran a poseerlas, no pudiendo hacerlo por ser contra lo ordenado por cédulas de su majestad. El presidente ordena que se den mandamientos a las justicias mayores para que cuando muera algún encomendero averigüen el estado de la encomienda y hagan relación a su señoría, y en el ínter no se dé posesión hasta que su señoría provea. Los encomenderos que carezcan de título lo pedirán a su señoría dentro de dos meses, conforme a cédula real. Esta orden se extendió a Honduras, Chiapa y Costa Rica. ${ }^{72}$

Es claro que este presidente tendía a que las encomiendas no se extendieran a más de dos vidas, conforme a la antigua ley de sucesión de 1536. ${ }^{73}$ Pero los informes que había recibido muestran que en esta jurisdicción las familias de los encomenderos procuraban de hecho, como en México, gozar de las encomiendas por más tiempo del autorizado por la ley. Es sabido que en varios reinos de las Indias se "disimuló" en esta materia, aprobando la Corte la concesión de otras vidas hasta la quinta. ${ }^{74}$

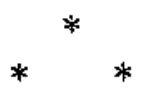

Veamos ahora algunas peculiaridades con respecto a las ayudas de costa y provisión de encomiendas.

El mismo presidente de la Audiencia de Guatemala, licenciado

72 AGG., Mercedes y Nombramientos. A. 1. 39. 1751. Fol. 13.

23 DIU., X, 322-327. DII., XLI,198-204. Puga, Provisiones..., I, 368-370.

74 Cfr. mi Encomienda Indiana, cit., p. 177. Y más adelante la pág. 68 del presente estudio. 
Pedro Mallén de Rueda, en la ciudad de Santiago, a 24 de diciembre de 1590, comunicó a los Oficiales de la Real Hacienda que el Rey, por cédula de Madrid de 7 de mayo de 1576, tenía mandado que, de los tributos de los pueblos que se quitaron a los gobernadores y oficiales reales y demás personas en ella contenidas, se repartiesen ayudas de costa a los conquistadores y pobladores antiguos que no tenían encomienda y a sus hijos e hijas y demás personas beneméritas. En esta virtud, el presidente hizo repartimiento a diversas personas de 5,290 tostones, según se detalla en el documento. ${ }^{75}$ Estas ayudas de costa se pagaban a base de los tributos de los indios, pero no tenían la categoría de las mercedes de encomienda.

Las últimas se seguían proveyendo en la gobernación de Guatemala. Así, en la ciudad de Santiago, a 13 de abril de 1590, el presidente Mallén de Rueda, habiendo visto lo pedido por parte de Alonso de Aguirre, vecino de la ciudad de Gracias a Dios, sobre que se le encomendara el pueblo de Guaxinlaga, que vacó por muerte de Antón de Murcia, dijo que en nombre de su majestad hacía merced a dicho Aguirre de nueva encomienda de los indios del citado pueblo "con todos sus barrios y subjectos, según y como los tuvo e tenía e poseyó el dicho Antón de Murcia, difunto, y mandó que se le dé título de encomienda en forma". ${ }^{76} \mathrm{El} 20$ de julio de 1590, el presidente Mallén recibió una petición de Magdalena de Mondragón, viuda de Juan Méndez, vecino que había sido de la villa de Choluteca, sobre que se le hiciera merced de encomendar el pueblo de Nacaome, que vacó por muerte de dicho su marido, en Esteban de Amaya, con quien había concertado casarse. El presidente concedió lo pedido a condición de que Amaya no tuviera otros indios de encomienda, pues caso de tenerlos, esta merced sería ninguna y los indios dichos quedarían vacos para poderlos encomendar o otra persona. ${ }^{77}$ En la ciudad de Santiago, a 23 de octubre de 1593, el presidente Mallén dió por título de primera encomienda a Diego de Quesada, vecino de la ciudad de Cartago de la

75 AGG., Mercedes y Nombramientos, A. 1, 39, 1751. Fols. 17v-18v,

76 AGG., Mercedes y Nombramientos. A. 1. 39. 1751. Fol. 10.

77 AGG., Mercedes y Nombramientos. A. 1. 39. 1751. Fol. 11. 
provincia de Costa Rica, los pueblos de Oruja y Ayeguaba "con los caciques y naturales de los dichos pueblos, barrios y estancias dellos", con tal que no tuviera otros indios en encomienda; industriaría en la fe a los que se le encomendaban y guardaría las ordenanzas dadas en pro de los naturales; se le daria título. ${ }^{78}$ En la ciudad de Santiago, a 22 de octubre de 1594, el doctor Francisco de Sande, presidente de la Audiencia de Guatemala, dió por título de primera encomienda a Pedro de Cuéllar, vecino de la ciudad de Valladolid del Valle de Comayagua, los pueblos de Tavlabe y Oricapala "con sus barrios y estan. cias"; se le daría título con las cláusulas ordinarias. ${ }^{79}$ En la ciudad de Santiago, a 26 de marzo de 1611, el doctor Alonso Criado de Castilla, presidente de la Audiencia, dijo que en nombre de su majestad depositaba y encomendaba por título de nueva encomienda en Miguel de Guebara, vecino de la ciudad de León de la provincia de Nicaragua, y en Francisco Lobo, vecino de esta ciudad, la parte de los pueblos de Chinandega y Pocoltequilla que vacaron, para que los gozaran por mitad en las especies que los indios estaban tasados, por dos vidas conforme a la ley de la sucesión, la suya de cada uno y la de su heredero en segunda vida, con la propiedad de toda la dicha encomienda al dicho Guebara, de manera que si Lobo muriera sin heredero o éste muriera, sucedería en todo el repartimiento y encomienda Guebara o su heredero en segunda vida; si hubiere aumento o disminución en dichos pueblos sería por cuenta de los encomenderos; tendrían cargo de enseñar a los naturales en la fe y guardarían las ordenanzas hechas o que se hicieran en favor de los indios y sus últimas tasaciones; traerían confirmación de su majestad dentro de cuatro años conforme a la cédula real de Madrid de 12 de octubre de 1608; si no lo hacían dentro de ese término, los Oficiales Reales meterian los tributos en la Real Caja, hasta que trajeran la referida confirmación; se dejaba a salvo el derecho de Guebara para recibir más merced en indios en remuneración de sus servicios. ${ }^{80}$ Don Antonio Peraza de Ayala y Roxas, Conde de

78 AGG., Mercedes y Nombramientos. A. 1. 39. 175l. Fol. 45v.

79 AGG, Mercedes y Nombramientos. A. 1. 39. 1751. Fol. 56.

80 AGG., Mercedes y Nombramientos. A. 1. 39. 1751. Fols. $120 \mathrm{v}-122$. 
la Gomera, presidente de la Audiencia de Guatemala, concedió una encomienda en 29 de agosto de 1613, "con todos los caciques y principales indios y vecinos dellos y sus barrios y estancias y lo demás a ellos anexo y perteneciente". ${ }^{81} \mathrm{El}$ mismo presidente, en 20 de diciembre de 1613, otorgó la encomienda de dos parcialidades, una de quince tributarios y otra de veintidós. ${ }^{82} \mathrm{Y}$ en 17 de mayo de 1615 , al conceder otra merced, no sólo mencionó el número de los tributarios encomendados, sino que especificó ser, por última tasación: cuarenta y cuatro casados, un viudo, un casado con mujer reservada, un soltero y nueve viudas; y cada casado pagaba una tela de algodón de seis varas de largo y tres cuartas de ancho, una gallina de Castilla, un cuar. tillo de miel, medio almud de frisoles y fanega y media de maíz; y cada viudo y cada casado que tenía reservada la mujer y cada soltero, una fanega y media de maíz, una gallina de Castilla, un cuartillo de miel y medio almud de frisoles; y cada viuda, una tela de cuatro varas de largo y tres cuartas de ancho cada año. ${ }^{83}$

Elijo los ejemplos anteriores para que se vea la evolución de los registros de la provisión de encomiendas hasta que se llega a incluir el detalle de los tributarios y tasas.

En otro título, más tardío y completo, dado en 1660 por el presidente de la Audiencia de Guatemala a favor del capitán Pedro Bermudo, sobre una parcialidad de indios en Chiapa que vacaron al morir el anterior encomendero que los gozaba en segunda vida, no sólo se especificó lo que tributaban los indios, sino el valor de las especies en que pagaban sus tasaciones. ${ }^{84}$

Aparte la inclusión de estos pormenores, que no suele hacerse en los títulos de encomienda sino en otros textos, me parece que la documentación guatemalteca se apega a las normas generales que regían en las Indias con respecto a la institución de que nos venimos ocupando. Desde luego no ofrece rarezas ni desviaciones de las formas establecidas, como ocurre en provincias alejadas de los centros guberna-

81 AGG., Mercedes y Nombramientos. A. 1. 39. 1751. Fol. 135v,

82 AGG., Mercedes y Nombramientos. A. 1. 39. 1751. Fol. 152v.

83 AGG., Mercedes y Nombramientos. A. 1. 39. 1751. Fol. 165v.

84 AGG., A. 3. 16. 31505. 2072. 
tivos principales, por ejemplo, en Paraguay. La presencia en Guatemala de una Audiencia compuesta por letrados creo que basta para aclarar la razón de la regularidad apuntada.

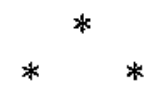

Creo oportuno mostrar cómo se daba posesión de una encomienda en esta Audiencia. Ante el presidente don Antonio Peraza de Ayala y Roxas, Conde de la Gomera, hizo relación don Pedro Núñez Barahona y Loaysa, vecino de la ciudad de Guatemala, que era hijo legítimo y el mayor por no haber otro seglar de Sancho Barahona y doña Isabeì de Loaysa, ya difuntos, encomendero de la mitad del pueblo de Santiago Atitlan y sus estancias, y como tal había sucedido en dicha encomienda y transferídose en él por ministerio de la ley la posesión civii de la misma, sin ser necesario otro ningún acto de aprehensión, conforme a derecho y a la ley de la sucesión y a una real cédula que presentó en que el Rey concedió tercera vida en dicha sucesión al dicho su padre. A mayor abundamiento pidió que por nuevo acto se le diese posesión. Mandósele dar y, para el efecto, el 8 de abril de 1623, se congregaron el gobernador, alcaldes y regidores de Atitlan como cabecera a la que estaban sujetos los demás pueblos, estancias y milpas, de donde también concurrieron indios. El escribano comisionado para ello tomó de la mano al gobernador, alcaldes, regidores, alguacil, escribano y otros indios:

"y uno a uno los fué recibiendo por un brazo el dicho don Pedro Núñez Barahona y Loaysa, y dellos en voz y en nombre de los dichos sus pueblos, cabildos y comunidades y demás indios y sus tributos que agora son y adelante fueren. .. di la posesión real al dicho..., el cual la tomó y aprehendió quieta y pacíficamente sin contradicción alguna, y en ella lo amparé y estoy presto de lo defender, y el dicho gobernador, alcaldes y demás indios dixeron que estaba así muy bien y que quedaban alegres sus corazones y que el dicho encomendero los ayudase y defendiese". 


\section{A continuación vienen las tasaciones de los tributos. ${ }^{85}$}

La posesión se da, en consecuencia, sobre los indios y sus tributos. Ya hemos visto que los títulos de encomienda en Guatemala no hacen mención alguna al derecho de la tierra; la misma significativa omisión se advierte en el acto posesorio. Es interesante, desde el punto de vista de la sucesión, que la encomienda de que tratamos se hubiera extendido a la tercera vida por una cédula especial del Rey. La inclusión de la tasa en el expediente de posesión es otra prueba de la publicidad que se acostumbraba dar en Guatemala al ajuste legal de las prestaciones que podía exigir el encomendero a sus indios.

En La Encomienda Indiana señalé la existencia de una política fiscal que tendía a aumentar los ingresos de las cajas reales a costa de las rentas que por concepto de tributos de indios percibian los encomenderos. A este género de medidas corresponde un auto que dió en la ciudad de Santiago de Guatemala, a 3 de agosto de 1689, el presidente de la Audiencia, don Jacinto de Barrios Leal, en el que mandaba, conforme a real cédula de 2 de septiembre de 1687, que se embargaran todas las encomiendas que en pueblos de indios de esta jurisdicción estaban situadas a diferentes personas, así de los vecinos de esta ciudad como de los de fuera de ella, por tiempo de cuatro años, debajo de las calidades que en dicha real cédula se expresaban. Y por cuanto las más de dichas encomiendas estaban con el gravamen de pensiones, mandaba que se certificara el número de ellas, sin excepción, para informar a su majestad. ${ }^{86}$ La cédula real aludida habia ordenado el desfalco de la mitad de las rentas de las encomiendas, durante cuatro años, a partir del primero de enero de 1688; el objeto era obtener fondos "para mantener fuerzas marítimas en Sur y Norte, con que defender los puertos y costas de piratas que los infestan". En 1691 se prorrogó el descuento hasta el primero de enero de 1695, fecha en que debió terminar, según cédula expresa de 28 de abril de 1694. ${ }^{87}$

85 AGG., A. 1-1. Exp. 10. Leg. 1.

86 AGG., A. 3. 16. 26409. 1603.

87 Archivo Histórico Nacjonal. Madrid. Cedulario Indico, XXIV, fol. 50 b, núm. 33. Véase también el tomo XXXVIII, fol. $61 \mathrm{~b}$, núm. 5 . 
En el siglo siguiente se encuentra un despacho de 21 de octubre de 1734 sobre que no se pague la encomienda a la persona que la goza en Indias y reside en España sin que su fe de vida se autorice por la Secretaría del Supremo y Cámara de las Indias. Larga vigencia tuvo esta orden, porque todavía en 1 de enero de 1788, en Madrid, se extiende con tal propósito la fe de vida de don Vicente Joaquín de Maturana, que era vecino de la corte. ${ }^{88}$

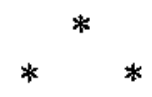

En el Archivo de Guatemala he hallado algunas noticias sobre tributos, que pondrán fin a esta parte de nuestro estudio. Creo que en esta región, como en tantas otras de Indias, es factible un análisis provechoso de las matrículas y tasaciones, pero yo no puedo presentar sino algunos datos sueltos.

En el libro de los tributos de los pueblos del valle de Guatemala, año de 1542, se anotan las partidas que se venden en almoneda, sobre todo de cacao. ${ }^{89}$

En una cuenta general del ramo de tributos de la Real Caja de Guatemala se hallan datos del año de 1685 sobre el cobro del tostón en las jurisdicciones de San Miguel y Chuluteca, por valor de 1,210 tostones. ${ }^{90}$ Lo cobrado de los naborios en ambas provincias montaba 190 tostones. Los tributos cobrados de Sesore y Osolutan, pueblos puestos en la Real Corona, ascendían a 180 tostones y 3 reales. Había siete pueblos vacos que tributaban 1,433 tostones y 1 real. Y nueve partidas del derecho de Barlovento habían rendido 600 tostones y 1 real. 91

Existe también un estado de los tributos pagados por los pueblos del valle de Guatemala según tasaciones del año 1710. Por vía de

\footnotetext{
8B AGG., A, 3, 16, 38490, 2605.

AGG. A. 3. 16. 36516. 2501.

90 Además de los tributos ordinarios, la Corona impuso a los indios ciertos servicios o pedides extraordinarios, como el del "tostón" para los indios de Nueva España, expresando como motivo "las públicas necesidades que ocurrieron el año presente de $159 \mathrm{l}$ ". Cfr. Recopilación de Indias, ley 16 , título 5, libro 6 .

91 AGG., A. 3. 16. 38234. 2599.
} 
ejemplo se encuentra que el pueblo de Teottega, del Marqués de Monte Alegre, tiene los siguientes tributarios: uno entero, diez en otros pueblos, tres casados con laborias, uno casado con reservada, dos solteros, doce indias casadas en otros pueblos, una con mulato y una viuda. Paga de doctrina: 11 pesos, 6 reales y 28 maravedís. Da por servicio (parece ser del tostón) 16 tostones. Y además tributa: 10 mantas y 1 pierna; 17 fanegas de maíz de primera y 8 fanegas y 6 almudes de maíz de segunda; 17 gallinas; 17 medios de frixoles; 17 medios de sal; y 1 fanega y 4 almudes de granada. ${ }^{92}$

$Y$ para concluir, examinemos un testimonio de los autos en que constan las providencias para que las indias no tributen. El 13 de septiembre de 1754 se envía real cédula a la Audiencia de Guatemala sobre que los indios, sin distinción de casados o solteros, tributen desde los 18 hasta los 50 años cumplidos y que las mujeres no paguen. Esto último no se puso en práctica hasta tener nueva decisión de España, porque había una cédula de 21 de marzo de 1702 que mandó guardar la costumbre y continuar cobrando el tributo a las mujeres; en Guatemala había sido y era costumbre que las indias casadas lo pagaran. Posteriormente, en Buen Retiro, a 11 de diciembre de 1756, se resolvió que la cédula de 1702 no hizo especial derogación de la ley 19, título 5, libro 6 de la Recopilación de Indias ni precedió consulta a fin de que tuviera fuerza de ley, por lo cual debía observarse lo dispuesto en 13 de septiembre de 1754 y dicha ley 19 sobre que las mujeres no pagaran tributo. Se obedeció en Santiago de Guatemala el 29 de junio de 1757. El fiscal opinó que se debía cumplir y publicar, y así lo proveyó la Audiencia en 11 de julio de 1757.

Con este motivo, el contador de cuentas reales informó que el par de casados naturales de un mismo pueblo contribuía enteramente el tributo de su tasa, siendo los que constituían la primera clase de indios tributarios. Los casados con indias de otros pueblos, con menores, con reservadas y ladinas, los solteros y viudos, que se nominaban medios tributarios, ahora pagaran a la mitad, tercia, cuarta, quinta u

92 AGG., A. 3. 16. 34262. 2320 . 
otra parte de lo que pagaban los primeros, eran los que constituían la segunda clase. Y los que componían la tercera eran las indias casadas con indios de otros pueblos, con laborios y ladinos, las viudas y solteras, siendo esta clase la que por lo más regular pagaba menos tributo que las otras. Explicaba el contador que esta separación de clases fué consecuencia precisa de la diversidad de especies y efectos que les fueron tasados y pagaban, no sólo por lo respectivo a las provincias, sino entre los indios de un mismo pueblo, regulándose en particular y después en general lo que cada clase debía pagar, por lo cual, $\mathrm{e}$ incluyéndose indistintamente lo que unas y otras debían contribuir en las partidas o sumas de la regulación que conforme a sus tasas se les hacía, se dificultaba poder dar razón en corto tiempo, generalmente, del exceso que había entre lo que pagaban los casados de la primera clase y lo que correspondía a los solteros, y sólo podía informar por ahora que el casado de la primera clase pagaba tanto como el medio tributario, porque pagando el par de casados cuatro reales y una fanega de maíz, pagaba cada uno de los dos individuos a dos reales y media fanega de maíz, que era lo mismo que contribuía el que era realmente medio tributario; si resultaba exceso, provenía del más o menos número de indios en las clases que comprendían las tasaciones.

Del expediente resulta que en los partidos de Esquintla y Guazacapan, a más del servicio del tostón, se pagaba tributo en dinero, cacao a 11 pesos y 4 reales la carga, maíz a 4 reales la fanega, gallinas a 2 reales y miel a real el cuartillo.

El 6 de septiembre de 1757, la Audiencia mandó librar despachos a todos los corregidores, gobernadores y alcaldes mayores para que no se cobrara tributo alguno a las indias de cualquier clase que fueran.

Hubo algunas dudas con respecto a lo que debía devolvérseles del último tercio de tributos cobrado, y acerca de si debían quedar exentas de pagar el servicio del tostón.

El fiscal fué de parecer que a la casada con tributario se le devolviera la mitad de lo pagado por ambos casados, y que el servicio de los 
cuatro reales (o sea, el llamado del tostón) quedara todo a cargo del marido.

La Audiencia declaró finalmente, el 16 de febrero de 1758, que el indio casado debía pagar en lo sucesivo lo mismo que hasta entonces contribuía el casado con ladina o reservada y que las indias quedaban relevadas del servicio del tostón. Un escrito posterior aclara que el casado con ladina o reservada pagaba como si fuera soltero.

El fiscal de su majestad interpretó que el auto de la Audiencia significaba que en lo sucesivo se cobraría a los casados lo propio que a los solteros, relevando de la mitad del tostón a las indias y a los varones.

En la ciudad de Guatemala, a 7 de marzo de 1758, la Audiencia confirmó su auto de 16 de febrero y mandó que los alcaldes mayores devolvieran lo que en esta razón hubieran exigido de más a los indios. En 13 de marzo se libraron veintitrés despachos para el cumplimiento.

El expediente aclara también que, en diversos pueblos, el tributo del varón soltero era la mitad del correspondiente al tributario entero, mientras que la india soltera pagaba en todos los casos menos de esa mitad antes de la reforma que acabamos de analizar. ${ }^{93}$

De manera que puede afirmarse que la costumbre en Guatemala había sido que tributaran algunas mujeres indias tanto solteras como casadas, y es lo que modificó substancialmente la legislación de mediados del siglo XVIII.

Valdría la pena estudiar en las cuentas de tributos, a partir de entonces, la repercusión económica del cambio, así en lo que respecta a los ingresos fiscales, o sea, los tributos pertenecientes al Rey, como a las encomiendas, esto es, los tributos destinados a los particulares.

93 AGG., A, 3. 16. 26475, 1608. 



\section{LOS SERVICIOS PERSONALES}

Con independencia de la esclavitud y las encomiendas, existió en Guatemala, al igual que en México, el repartimiento forzoso de indios para determinados servicios.

Las tandas se calculaban en esta región a base de la cuarta parte de los tributarios, se remudaban por periodos semanales y mediaba paga de salarios, por lo común, de un real y de real y medio por día; pero el trabajador carecía de libertad para escoger la clase de ocupación y el amo a quien serviría, pues ambas cosas las determinaba el juez encargado de hacer los repartimientos. ${ }^{94}$

Hubo ciertamente otros indios que se concertaban a servir por su voluntad; pero la importancia de los repartimientos como medio de obtener la mano de obra es obvia en la sociedad colonial guatemalteca, desde el siglo XVI hasta fines del XVIII por lo menos.

$\mathrm{El}$ primer documento que encuentro acerca de la institución aludida es una provisión real que, a nombre del rey don Felipe, da la Audiencia de México, integrada por los doctores Reynoso, Orozco y Villanueva, en la ciudad de México, a 28 de junio de 1565. Va dirigida al gobernador de la ciudad de Santiago de Guatemala, y en ella se explica que ante la citada Audiencia pareció Juan de Salazar, en nombre del cabildo de la ciudad de Santiago, e hizo relación que en esta ciudad y sus términos había muchos vecinos labradores que sembraban sus tierras de trigo para el proveimiento de la ciudad y su

94 Cr. L. B. Simpson, Studies in the Administration of the Indians in New Spain, Berkeley, 1938, (Ibero-Americana 13), y S. Zavala y M. Castelo, Fuentes para la Historia del Trabajo en Nueva España, México, 1939-1945, 6 vols. y 2 en prensa. 
comarca, y que por no darles indios que les beneficiasen dichas sementeras se venían a perder, de que todos los vecinos padecían mucha necesidad, y de ella resultaba hambre por haber falta de trigo. Añadía que podría remediarse con mandar a los gobernadores de esa provincia que hiciesen repartimiento de gente de los pueblos más cercanos a la ciudad para el beneficio de dichas sementeras, pagando a cada trabajador cuatro reales de plata cada semana. Visto por el presidente y oidores de México, mandan que el gobernador de Guatemala vea la necesidad que los vecinos españoles de la ciudad de Santiago y su provincia tienen de ser socorridos con gente para el deshierbo y cosecha de sus labranzas de trigo, conforme a lo cual proveerá y darä orden como se les dé alguna gente de los pueblos más cercanos a los tiempos necesarios, según la cantidad de las labranzas y gente de los tales pueblos, con la menos vejación que sea posible, y que se les pague su trabajo a los mismos que se ocuparen en dicho beneficio, conforme a lo que en esa tierra se acostumbra. ${ }^{95}$

Es de advertir que la provisión no trae al dorso constancia de haber sido pregonada, a diferencia de lo que ocurre con otras muchas conservadas en el Archivo guatemalteco. Pero en caso de haber sido obedecida, podría considerarse como el instrumento legal que autorizó la introducción en Guatemala de los repartimientos de servicio para labores agrícolas, existentes en México desde mediados del siglo XVI.

Ya sea por esta vía u otra que desconocemos, lo cierto es que en la segunda mitad de la centuria citada se establecen y funcionan normalmente los repartimientos de servicio en Guatemala. En efecto, en la ciudad de Santiago de la provincia de Guatemala, en 18 de septiem. bre de 1589, el licenciado Pedro Mallén de Rueda, presidente de esta Audiencia, gobernador y capitán general en su distrito, dijo que:

"por cuanto los corregidores que han sido de valle de esta ciudad han tenido de uso y costumbre repartir los indios que se dan para el servicio ordinario de ella y para las labranzas, trapiches y estancias de los vecinos y para las obras públicas y han tenido jurisdicción en los

gs AGG., A. 1. 2-4. 2196. 134. 
pueblos de los naturales de donde viene el dicho servicio, por tanto, para que en esto se guarde la costumbre y se haga con la rectitud y diligencia que conviene, mandaba y mandó que se dé su comisión en forma a don Pedro de Rueda, corregidor del valle de esta ciudad, para que por todo el tiempo que ejerciere el dicho cargo, demás de la jurisdicción que por la provisión real del dicho su oficio se le da, la tenga asimismo en todos los pueblos de esta comarca y milpas de este valle de donde vienen y es uso y costumbre de se traer los indios para los dichos servicios, y para que haga el dicho repartimiento según y como y en la forma y manera que los demás corregidores que han sido del dicho valle lo han hecho y podido y debido hacer, y que por razón dello haya y lleve todos los derechos y aprovechamientos que los dichos corregidores sus antecesores han llevado, podido y debido llevar y por ello les pertenece, la cual dicha jurisdicción tenga en lo tocante a los indios del dicho repartimiento y a las cosas a él anexas y concernientes". 96

El propio presidente Mallén de Rueda, en Santiago de Guatemala, a 31 de octubre de 1589, mandó dar comisión a Francisco de Villalta Balenzuela, vecino de la ciudad de Gracias a Dios, para que tuviera cargo de repartir los indios del servicio ordinario y para labores del campo, sementeras y edificios de casas y estancias entre los vecinos de dicha ciudad, según lo usó Pedro de Gomara de Reynoso, y por la instrucción que tuvo Jusepe Ramos, persona que primero usó el dicho oficio, y podría llevar los derechos y aprovechamientos que por ello llevaba el mencionado Gomara. ${ }^{97}$

El mismo presidente Mallén de Rueda, en Guatemala, a 8 de febrero de 1590, da nombramiento de alcalde mayor de las minas de Honduras a don Rodrigo de Fuentes, expresando "que si fuera necesario para el aviamiento de las dichas minas sacar algunos indios de cualesquier pueblos, los pueda sacar". ${ }^{98}$

Por lo tanto, entre los repartimientos autorizados en distintos lu.

96 AGG., Mercedes y Nombramientos, A. 1, 39. 175I. Fol. 3.

97 Ibid., fol. $4 \mathrm{v}$.

98 Ibid., fol. $7 \mathrm{v}$. 
gares de la jurisdicción de la Audiencia figuran: los de servicio ordinario de la ciudad; los de edificación; los de labranzas, trapiches y estancias; los de obras públicas; $y$, en caso necesario, los de minas.

En lo que respecta a la ciudad de Guatemala, hallamos - poco tiempo después- que el presidente Mallén de Rueda, en mandamiento de 25 de agosto de 1593, dice haber sido informado que a causa de que los vecinos de la ciudad han ido en mucho aumento, los indios de servicio que se reparten cada semana en ella no alcanzan para cumplir con ellos, y se quedan muchas personas sin indios de servicio. Manda que en adelante el pueblo de Aguacatepeque dé cuatro indios y el de Malacatepeque cinco de servicio cada semana, los cuales vengan al repartimiento a esta ciudad para que con los demás indios se repartan a los vecinos de ella. Estos pueblos — se añade-- están a tres y cuatro leguas de la ciudad, no son pueblos de cacao y jamás han dado dicho servicio ordinario. Malacatepeque era entonces de la encomienda de don Alfonso de Robledo.

El cacique y un alcalde de este último pueblo representaron que eran agraviados con lo mandado, porque nunca habían dado ese servicio, ya que el pueblo distaba seis leguas de la ciudad y era de tierra caliente, y sus habitantes tenian cacaguatales de donde se sustentaban y pagaban su tributo; la tierra de Guatemala era fría y enfermarian; su majestad había mandado por sus cédulas que no se llevaran indios de partes calientes a frías; pedían, por último, que no se les obligara a dar los indios.

Esta petición fué denegada por el presidente de la Audiencia en 26 de agosto de 1593. Los indios de Malacatepeque apelaron ante la Audiencia. El presidente respondió que el caso era de gobierno y el auto estaba justificado, por lo que no había lugar a la apelación. La parte de los indios insistió en el recurso ante la Audiencia y expresó agravios.

El procurador síndico de la ciudad contestó que de otros pueblos de tierra caliente venían al servicio los indios y no enfermaban, por ser muy bueno el temple de esta ciudad; agregó que venían indios e indias de más de siete leguas y que el pueblo de Malacatepeque no 
distaba más de cinco, de suerte que estaba comprendido en la cédula de su majestad. No obstaba decir que eran de tierra de cacao y que si venían al servicio se perderían las milpas, porque no embargante que era tierra de cacao, las milpas eran de temporal y no de beneficio y regadío, y así no tenían trabajo ninguno en el beneficio de ellas. ${ }^{99}$

No se encuentra en el expediente la sentencia final de la Audiencia; sin embargo, el litigio examinado nos permite apreciar algunas costumbres que se habían creado en torno al repartimiento de indios para la ciudad de Guatemala.

De la misma materia trata la orden que dió en Santiago de Guatemala, el 29 de diciembre de 1594, el presidente doctor Francisco de Sande, en la que expresa que es necesario nombrar persona que reparta los indios de servicio ordinario que vienen a esta ciudad cada semana y acuden a ella para los edificios y reparos de las casas de dicha ciudad, y asimismo que reparta los indios que han de entender en el beneficio de las labranzas (de trigo) de la comarca y términos de esta ciudad, como lo han hecho los corregidores que han sido del valle de la misma. En tal virtud, nombra para el cargo a Alonso de Liebana. 100

Después, un auto acordado de 9 de enero de 1597 determina que los indios que se reparten para el servicio ordinario de las ciudades y villas sólo sean ocupados en los servicios ordinarios para que se les reparte y no en extraordinarios ni fuera de casa. 101

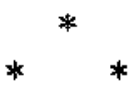

Mientras el repartimiento forzoso de servicios seguía el curso que

99 AGG., Paquete 357. Exped. 4.

100 AGG., A. 1. 39. 175I.. Fol. 58v.

101 Recopilación sumaria' de los autos acordados de la Real Audiencia de este Reyno de Guatemala, providencias y bandos de su Superior Gobierno, que han podido recogerse desde el año de 1561 hasta el presente de 1807, dispuesta en ordcn alfabético por don José María Zamora de orden del mismo Tribunal de la Real Audiencia, compuesto de los SS. Ministros D. Francisco Camacho y D. Antonio Rodriguez de Cárdenas. Nueva Guatemala. Año de 1807. AGG., A. 1. 25. Expediente 10357. Legajo 1702 (278 folios). EI auto acordado a que se alude en el texto se halla bajo la voz "Repartimientos", fol. 229. 
ponen de manifiesto los documentos anteriores, surgió asimismo en Guatemala el problema de las deudas de los trabajadores.

Un auto acordado de 2 de junio de 1584 dispuso que no se hicieran conciertos con los indios, si no fuere pagando al arriero el viaje que hiciere, $\mathrm{y}$ al indio oficial sólo un mes adelantado, y si más se les diere no se pudiera cobrar de ellos. 102

Otro acordado de 12 de septiembre de 1584 ordenó que si los mestizos, indios y mulatos asentados con cualesquier personas para hacer tintas o estar en estancias de ganado o para otros cualesquiera servicios, habiendo recibido para ello dinero en parte de pago y comenzado a servir, se ausentaren sin cumplir la obligación del asiento, por el mismo hecho incurrieran en la pena de servir cuatro meses en el tal ministerio, sin salario alguno, aplicando la paga de los dos a la Cámara de su majestad y la de los otros dos al amo de cuyo servicio se ausentaren; y si por segunda vez lo hicieren, fuera esta pena doblada y se les dieran cien azotes, 103

En 16 de febrero de 1590 se permitió, por otro auto acordado, que se pudiera dar adelantado a los trabajadores que se concertaran el salario de tres meses. 104

Más adelante, un acordado de 19 de julio de 1634 mandó:

"Que a ningún indio que entrare en el servicio de otra persona se le puedan dar dineros adelantados, pena de que en el mismo hecho los pierda el que se los diere, y asimismo que ninguno preste, ni fíe a los indios dineros ni mercaderías en poca, ni en mucha cantidad, si no es interviniendo el señor Fiscal en las obligaciones como su Curador, pena de perdimiento del principal con que se pueden quedar los indios, sin obligación de devolverlo, y de otra tanta cantidad en que igualmente se condena al que contraviniere, aplicada por tercias partes; y se declara que el mismo indio con quien se hace el trato pueda denunciar y ser testigo". 105

102 Recopilación sumaria.., cit., fol. 71v.

103 Ibid., fol. 167.

104 Jbid, fol 7 ly. y ss.

105 Ibid., fol. 141 . 
Por último, un auto del gobierno de 4 de septiembre de 1637 insistió en que no se diese nada al fiado a los indios. 106

Creo que estas disposiciones sobre conciertos y deudas no han de ser todas las que se dieron sobre tales materias en Guatemala durante la época colonial. En México existen muchas más hasta el siglo XVIII y tienden igualmente a imponer restricciones en cuanto al monto de las deudas legítimas; pero esto no impidió que el sistema del peonaje llegara a generalizarse y a subsistir aun en los primeros años de la centuria que vivimos. ${ }^{107}$

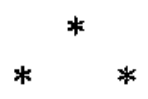

Volviendo al tema del servicio personal por vía de repartimiento, encontramos un auto del gobierno, de 22 de marzo de 1635, acerca de que se puedan repartir indios para la labor de tierras, teniendo consideración a que los que se señalaren con este fin no hagan falta a sus propias labores, y pagándoles su trabajo en plata diariamente. 108 En cambio, otro auto del gobierno, de 2 de abril de 1636, dispuso que las justicias no obligaran a los indios ni indias al servicio personal, como estaba mandado por cédulas de su majestad, y que a las indias no se les obligara por ningún caso a servir, ni salir de sus casas con título de molenderas ni otra ocupación. 109

Dada la concisión de estas órdenes, no es fácil deducir de su lectura la causa por que en tan corto plazo se sucedían las autorizaciones y prohibiciones del servicio personal, ni el verdadero alcance de unas y otras medidas. Pero acaso no sobra tener en cuenta que el virrey

106 Ibid., fol. 143.

107 Clr. mi estudio "Orígenes coloniales del peonaje en México", en El Trimestre Económico, Vol. X, No. 4 (México, Enero-Marzo 1944), pp. 711.748.

108 Recopilación sumaria., cit., fol. 248 y ss.

109 Loc. cit. La alusión a las cédulas reales se justifica, porque el 9 de abril de 1633 se envió una al presidente de la Audiencia de Guatemala sobre que quite a los indios del trabajo personal y los reduzca a que paguen sus tributos en los frutos, cosas y especies que parecieran más acomodadas. AGI., 139-7-9-III, 64. Debo este dato a don José Torre Revello. 
de México, Marqués de Cerralbo, a 31 de diciembre de 1632, había resuelto:

"que desde el primer día del año que entra de 1633 en adelante todos los jueces repartidores de repartimientos que no fueren para minas cesen en el uso destos oficios, dejando a los indios en su libertad para que sirvan a quien mejor partido y tratamiento les hiciere, o se ocupen en lo que les fuere más conveniente, y las justicias los amparen en esto sin consentir que en ello se les haga violencia ni compulsión". 110

Precisamente por aquellos años se habían renovado las disputas sobre la condición de los indios y tachado de abusivos los repartimien. tos forzosos. Al parecer, Guatemala no permanecía ajena del todo a la reforma.

Pero en esta región no creemos que la supresión de los repartimientos de servicio llegara a cumplirse, pues por auto del gobierno de 27 de octubre de 1636 se mandaba que no se obligara a los indios del valle de Guatemala a más servicio del que por leyes y ordenanzas estaba dispuesto. ${ }^{111}$ Esto indica que algún servicio se reputaba aún como legal, aunque el auto no brinda mayores detalles.

En 4 de septiembre de 1637 dispuso el gobierno que las justicias, ni por su mano ni en otra manera ocupasen indios en hilados ni en otras cosas de su aprovechamiento, bajo las penas que imponían las cédulas de su majestad. $112 \mathrm{Y}$ el 17 de agosto de 1638, que los alcaldes de los indios, alcaldes mayores y demás justicias tuvieran entendidas las penas con que se prohibia en las cédulas reales el que se cargara a los indios. ${ }^{113}$ Ambas eran restricciones que sólo tocaban a particulares aspectos del trabajo de los indios.

Más adelante, el acordado de 10 de octubre de 1638 aclaraba que

$\$ 10$ Simpson, Studies. ., cit., p. 149. S. Zavala y M. Castelo, Fuentes. ., cit., VI, 621-623.

111 Recopilación sumaria..., cit., fol. 248 y ss.

112 Loc. cit.

113 Loc. cit. En el prŏpio lugar puede verse que la materia de las cargas había sido objeto de disposiciones anteriores: auto acordado de 16 de febrero de 1590 sobre que ningún indio cargue cal, pena al que lo obligare de 10 pesos de multa por cada vez, y al indio que de su voluntad lo biciere, 20 azotes en la plaza. $\mathrm{Y}$ decreto del presidente de 23 de noviembre de 1603 acerca de que no se cargue ningún indio con ningún género de cargana, aunque sea con su voluntad, ni con licencia del presidente y audiencia. 
los indios solteros, aunque estuvieran bajo la patria potestad, en llegando a los 16 años cumplidos, deberían acudir a los servicios públicos y a los repartimientos de las labores. 114 Luego en ambas ocupaciones seguían autorizadas las tandas de operarios forzosos.

En seguida hallamos otros autos del gobierno que revelan la subsistencia de los repartimientos destinados a las obras públicas: el 16 de marzo de 1639 se dispuso que al alcalde ordinario que hacía oficio de corregidor del valle tocaba el repartimiento de los indios destinados por ordenanza para obras públicas y otros ministerios. $\mathrm{Y}$ el 7 de junio del propio año, que el corregidor tuviera entendido que sólo se debían repartir indios para el servicio general de obras públicas con las limitaciones prevenidas, de manera que los pueblos no se gravaran con ningún pretexto de otros servicios. 115

El auto del gobierno de 20 de noviembre de 1639 estableció que en los despachos y mandamientos que se autorizaran por el superior gobierno para que se dieran indios para las fábricas, se pusiera cláusula de que dichos despachos quedaban en poder de las justicias de los pueblos para donde se libraban, dando éstas recibo de ellos y cuidando de saber si las obras a que se destinaban se habían acabado, y estándolo, cesarían de darlos para que se aplicaran a otras partes donde hubiera necesidad, y se excusara con esto el grave daño de que los criados y albañiles fueran a sacarlos para aprovecharse de su trabajo. ${ }^{116}$

En términos generales mandó el auto del gobierno de 25 de octubre de 1640 que no se repartiera a los pueblos más servicio del que tuvieran obligación. ${ }^{117}$

Y en la centuria siguiente, un auto del gobierno de 29 de marzo de 1707, todavía especificaba que los gobernadores y demás jueces de los partidos de este reino pusieran especial cuidado en cumplir los despachos del superior gobierno en que se repartian indios para el cultivo de tierras, obras públicas u otros ministerios, para los que no

114 Loc cit.

115 Ibid., fol. 229 y ss.

n6 Ibid., fol. 248 y ss.

137 Loc. cit. 
les exceptuaban las leyes, sin admitirles excusa alguna, pues cuando tuvieran que pedir, lo habrían de representar al mismo superior gobierno a quien tocaba privativamente examinar si había causas para relevar a los pueblos de tales servicios. Y sólo podrían los alcaldes mayores y gobernadores de las provincias que distaran de esta corte 50 leguas, dar los indios para aquellas obras públicas que no estuvieran a distancia de 10 leguas del pueblo, pagándoles su jornal en reales y mano propia, con más la ida y vuelta, haciéndoles buen tratamiento, y trabajando desde las 8 a las 12 de la mañana, y desde las 2 a las 5 de la tarde. 118

Finalmente, un acordado de 30 de enero de 1782 dispuso que el alcalde mayor y demás jueces ordinarios de la provincia de San Salvador tuviesen entendido que los mandamientos para repartimientos de indios tocaban privativamente al superior gobierno adonde deberían ocurrir los que los hubiesen menester para el trabajo de sus haciendas, que con conocimiento de causa y en lo que permitiese la cuarta parte, hechas las rebajas correspondientes de los exentos, con arreglo a las leyes, se les darían los que conviniesen, con las calidades de pagarles su jornal justo en mano propia, y los días de ida y vuelta a razón de seis leguas por día, desde las haciendas a sus pueblos; que no trabajasen sino ocho horas, se remudasen cada ocho días, y se les diese el tratamiento suave, racional y cristiano que merecían estos miserables, los más útiles del Reino. Y que igualmente tuviesen entendido que sus facultades sólo se limitaban a hacer que los indios, mulatos y de todas castas, sin reserva de los españoles plebeyos y vagos. trabajasen, cumpliesen los contratos y que se les diese su jornal, en consecuencia de las reales provisiones de esta Audiencia, sin excederse en más por ningún pretexto. 119

Las investigaciones de Simpson, fructuosas por lo que ve a Guatemala entre los años de 1734 y 1798 , confirman que los repartimien-

118 Loc. cit.

119 Loc. cit.

84 
tos de servicio continuaron en esta región para labores de campo y la edificación de la nueva ciudad, o sea, la capital actual del país. ${ }^{120}$

Me parece, en consecuencia de lo expuesto, que desde 1633 existe una diferencia entre México y Guatemala en lo que toca a la evolución del trabajo agrícola. En las advertencias a los volúmenes VI, VII y VIII de las Fuentes para la Historia del Trabajo en Nueva España, podrá verse que en este virreinato no subsiste el repartimiento forzoso para el campo en época tan tardía como ocurre en Guatemala. Esto no quiere decir que a la supresión del repartimiento haya seguido una completa libertad de los peones; pero las formas de sujeción siguieron otros rumbos que he procurado mostrar en mi estudio sobre "Orígenes. coloniales del peonaje", ya citado.

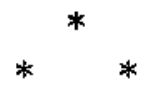

Para concluir observemos que, sin confundirse con el servicio forzoso, existió una política de parte del gobierno colonial tendiente a que los indios se aficionaran al trabajo, abandonando sus hábitos de ociosidad y descuido. Ya no se trataba de beneficiar en primer término a los colonos europeos como ocurría con el suministro de la mano de obra nativa; sino de que el trabajo del indio redundara también en una mejor condición para el mismo, en una recaudación más segura del tributo y en la mejoría general de la economía del Reino. Por ejemplo, un auto del gobierno de 24 de diciembre de 1680 ordenaba:

"los gobernadores, corregidores y alcaldes mayores, cuiden que los indios siembren y cultiven las tierras, y limpien sus cacaotales, para que den fruto, y tengan con que pagar sus tributos, obligándolos a ello con pena de azotes, y no otra: y no los compelan por manera alguna a que vayan a servir a los obrajes de tinta, y salinas, sin impedir que

120 Studies..., cit., pp. 99-116. Sólo encuentra un caso de minas en Guatemala, correspondiente a San Luis Xílotepeque, Chiquimula, 24 de julio de 1773. Ibid., p. 65. Los documentos proceden del Archivo del Gobierno, Guatemala, legajo especial sobre reparti. mientos. Ibid., p. 96. 
lo hagan voluntariamente en los tiempos en que se hallen desembarazados del cultivo de sus cacaotales". 121

Y todavía en términos más amplios, un acordado de 13 de noviem. bre de 1801 encargaba que los alcaldes mayores, corregidores, subdelegados y demás jueces, en cumplimiento de las leyes, cuidaran de la mejor policía de los indios, su empleo en oficios, labranzas u otros trabajos, libertad en todos sus tratos y en lo demás concerniente a su buen tratamiento; procuraran que los hombres y mujeres anduviesen vestidos e hiciesen sus siembras, y que estuviesen surtidos de todos los instrumentos necesarios para el trabajo; y coadyuvasen los curas con sus amonestaciones al exterminio de la ociosidad y adopción segura de una vida "ocupada y laboriosa". Y los mismos jueces administrarían pronta justicia a cualquiera que acudiera a ellos en demanda de deuda de los indios, y demás residentes en sus provincias, por razón de venta, socorro o anticipación, cuidando escrupulosamente que por nadie se hiciera repartimiento a los naturales, ni por origen de trato algún agravio con excesivas ganancias. 122

El repartimiento a que alude el documento no parece ser el de servicio, sino el de géneros que tanto se usó en las postrimerías del régimen español y por medio del cual las autoridades, prevaliéndose de su rango, vendían a los habitantes mercancías que, por la calidad y el precio, dejaban pingües ganancias.

La alusión a la deuda revela que este sistema de sujeción de los trabajadores continuaba en uso y contaba aún con la protección gubernativa.

121 Recopilación sumaria.., cit., fol. 146.

122 Ibid., fol. 148. 


\section{CONCLUSION}

Considero que el estudio de las instituciones coloniales de Guatemala es viable gracias al celo y la eficacia con que se han reunido $y$ ordenado los fondos del Archivo General. Esto no significa que el mismo cuente con el personal y recursos que necesita; pero en medio de todos los obstáculos, la voluntad de su director ha triunfado hasta el grado de hacer posibles las primeras investigaciones.

En cuanto a la riqueza de temas y al interés que ofrecen los aspectos particulares de las instituciones en Guatemala, creo que no es necesario insistir.

La evolución tan pronto se acerca como se diferencia de la de Nueva España y el estudio comparativo de ambas regiones contribuye a despejar muchas incógnitas.

Además, la Audiencia de Guatemala ejerció jurisdicción en vastas comarcas y sus decisiones rebasaron con frecuencia los límites territoriales de la actual república.

Téngase presente también que este antiguo reino, como se le llamaba en la época colonial, fué teatro y aún lo es de una de las confluencias más caudalosas de la cultura española con la indígena, razón por la que ilustra en condiciones excelentes la historia de las instituciones que derivaron de ese contacto.

Repito, por último, que mi investigación fué realizada en un plazo en extremo breve y que está muy lejos de haber agotado las posibilidades de continuar con fruto el estudio. Si a pesar de ello me animo a publicar la presente monografía, es porque no creo probable 
que pueda continuarla y quizá en su condición actual preste un servicio mayor que en caso de permanecer inédita.

Con todas sus deficiencias la ofrezco como un tributo a la amistad entre México y Guatemala, que no siempre ha sido cultivada en el ambiente intelectual con la asiduidad que merece.
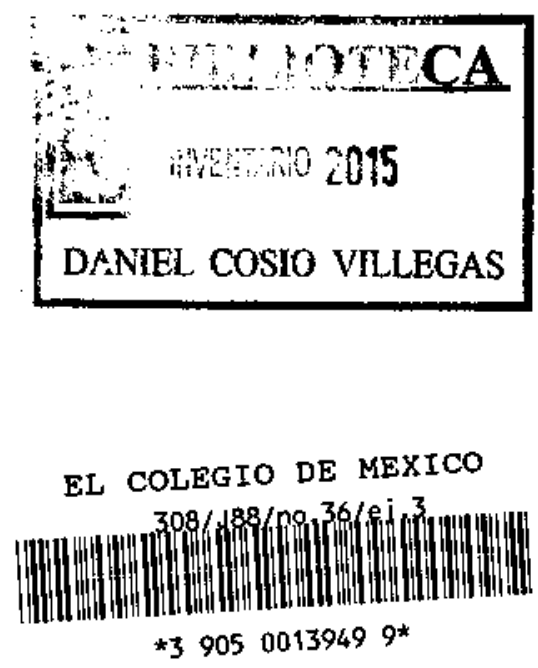


\section{LISTA DE JORNADAS PUBLICADAS}

1. José Medina Echavarría. Prólogo al estudio de la guerra (agotado).

2. Tomás Sánchez Hernández. Los principios de la guerra (agotado).

3. Jorge A. Vivó. La Geopolítica (agotado).

4. Gilberto Loyo. La presión demográfica (agotado).

5. Antonio Caso. Las causas humanas de la guerra. Jorge Zalamea. El hombre, náufrago del siglo $x x$.

6. Vicente Herrero. Los efectos sociales de la guerra (agotado).

7. Josué Sáenz. Los efectos económicos de la guerra.

8. Manuel F. Chavarría. La disponibilidad de materias primas.

9. Manuel M. Pedroso. La prevención de la guerra.

10. D. Cosío Villegas, E. Martínez Adame, Víctor L. Urquidi, G. Robles, M. Sánchez Sarto, A. Carrillo Flores, José E. Iturriaga. La postguerra.

Alfonso Reyes, D. Cosío Villegas, J. Medina Echavarría, E. Martínez Adame, Víctor L. Urquidi. La nueva constelación internacional.

11. Raúl Prebisch. El patrón oro y la vulnerabilidad económioa de nuestros paises.

12. José Gaos. El pensamiento hispanoamericano.

13. Renato de Mendonça. El Brasil en la América Latina.

14. Agustín Yáñez. El contenido social de la literatura iberoamericana.

15. José E. Iturriaga. El tirano en la América Latina.

16. Javier Márquez. Posibilidad de bloques económicos en América Latina.

17. Gonzalo Robles. La industrialización en Iberoamérica.

18. Vicente Herrero. La organización constitucional en Iberoamérica.

19. M. F. Chavarría, A. Pareja Díez-Canseco, M. Picón-Salas, J. A. Portuondo, L. Alberto Sánchez, J. Vasconcelos, Jorge A. Vivó, J. Xirau. Integración política de América Latina.

A. Castro Leal. La politica internacional de América Latina. 20. Francisco Ayala. Ensayo sobre la libertad.

21. J. A. Portuondo. El contenido social de la literatura cubana.

22. Antonio García. Régimen cooperativo y economía Latino-Ame. ricana. 
23. Jesús Prados Arrarte. El plan inglés para evitar el desempleo.

24. Florián Znaniecki. Las sociedades de cultura nacional y sus rela. ciones.

25. Renato Treves y Francisco Ayala. Una doble experiencia política: España e Italia.

26. John Condliffe. La política económica exterior de Estados Unidos.

27. A. Carneiro Leão. Pensamiento y acción.

28. Antonio Carrillo Flores. El nacionalismo de los países latinoamericanos en la postguerra.

29. Moisés Poblete Troncoso. El movimiento de asociación profesional obrero en Chile.

30. José María Ots Capdequi. El siglo XVIII español en América.

31. Medardo Vitier. La lección de Varona.

32. Howard Becker y Philip Fröhlich. Toynbee y la sociología sistemática.

33. Emilio Willems. El Problema Rurai Brasileño desde el punto de vista Antropológico.

34. Emilio Roig de Leuchsenring. 13 Conclusiones Fundamentales sobre la Guerra Libertadora Cubana de 1895.

35. Eugenio Imaz. Asedio a Dilthey. (Un ensayo de interpretación). 36. Silvio Zavala. Contribución a la historia de las instituciones coloniales en Guatemala.

Distribución exclusiva:

FONDO DE CULTURA ECONOMICA

Pánuco, 63 - México, D. F. 